\title{
Efficacy Study of Eggshell (ESC) and Alum Base Coagulant $(A B C)$ for the removal of Total Suspended Solids (TSS) from Cosmetics Wastewater by Coag-flocculation
}

OVUORAYE EGUONO PROSPER ( $\sim$ foreman028@gmail.com )

Federal University of Petroleum Resources Effurun https://orcid.org/0000-0003-2841-7708

Victor. I. Ugonabo

Dept. of Chemical Engineering, Nnamdi Azikiwe University Awka, Nigeria

Lawrence. C. Okpala

Dept. of Chemical Engineering, Nnamdi Azikiwe University Awka.

Gina. F Nwokocha

CCISS Centre for Power Engineering Training Program Calgary, Alberta Canada

\section{Research}

Keywords: Eggshell, Efficacy, Total Suspended Solids (TSS), Alum, Coag-flocculation, Environmental Protection Agency (EPA)

Posted Date: February 18th, 2021

DOI: https://doi.org/10.21203/rs.3.rs-206327/v1

License: (9) This work is licensed under a Creative Commons Attribution 4.0 International License. Read Full License 


\title{
Efficacy Study of Eggshell (ESC) and Alum Base Coagulant (ABC) for the removal of Total Suspended Solids (TSS) from Cosmetics Wastewater by Coag-flocculation Prosper .E. Ovuoraye.1, Victor .I. Ugonabo ${ }^{2}$, Lawrence .C. Okpala ${ }^{2}$, Gina .F Nwokocha ${ }^{3}$ \\ 1. Dept. of Chemical Engineering, Federal University of Petroleum Resources Effurun. \\ ${ }^{2}$. Dept. of Chemical Engineering, Nnamdi Azikiwe University Awka, Nigeria. \\ 3. CCISS Centre for Power Engineering Training Program Calgary, Alberta Canada \\ Corresponding Author E-mail'1 : foreman028@gmail.com.
}

\begin{abstract}
This study compares two coagulants: Alum Based Coagulant (ABC) and Eggshell Coagulant (ESC) used for the coag-flocculation treatment of cosmetic wastewater to determine the efficacy of ESC at optimum condition. The residual values of TSS particles in the wastewater were measured and recorded after the coag-flocculation treatment at 30mins settling time. The cubic models obtained following the Central Composite Design (CCD) were used to confirm the experimental predetermined optimal $\mathrm{pH}$ and dosage were recorded as: 6 and $0.3 \mathrm{~g} / \mathrm{L}$ for ESC, while $\mathrm{pH} 8$ and $0.1 \mathrm{~g} / \mathrm{L}$ were reported for $\mathrm{ABC}$. The optimal point plots $85 \%$ and $97 \%$ TSS removal efficiency which corresponds to $38 \mathrm{~g} / \mathrm{L}$ and $6 \mathrm{~g} / \mathrm{L}$ of residual TSS recorded for ESC and $\mathrm{ABC}$ respectively. The results obtained show that; the ABC and ESC driven coag-flocculation satisfied the EPA standard for wastewater discharge at optimal $\mathrm{pH}$. The cost remediation result shows that; ESC maintained significantly lower operating cost for wastewater treatment.
\end{abstract}

KEY WORDS: Eggshell, Efficacy, Total Suspended Solids (TSS), Alum, Coag-flocculation, Environmental Protection Agency (EPA) 


\subsection{INTRODUCTION}

Global cosmetic products market was valued around \$532billion in 2017 and is expected to reach

approximately $\$ 863$ billion by 2024 [1]. The cosmetics industry produces different kinds of wastewater. Few years ago, cosmetics production process do not fall within cosmetic regulations [2]; this development were accompanied with the increase in the generation of cosmetics wastewater contaminated with large amounts of dye, surfactants, oils, micro beads, emulsion, and total suspended solids from different production sites across the globe [2]; [3].

The level of TSS contaminants present in the cosmetics wastewater poses serious industrial and environmental concerns. If not properly treated before their discharge high TSS levels can causes water to lose its ability to support aquatic lives [5]; it can also reduce the efficiency of wastewater treatment operations, contributes to clogs in tanks and pipes or aid corrosion [18]. Their complex characteristics pose severe resistance to unit operations which undergoes in industrial wastewater treatment plants [9]. Hence; the importance of TSS removal during wastewater treatment before discharge cannot be over emphasized.

According to the World Health Organization (WHO), TSS volumes in wastewater should not exceed 40mg/L for discharge [10]; as such; cosmetic wastewater with TSS contents greater than the set standard is considered a point source pollutant. The Environmental Protection Agency (EPA) has created several standards for wastewater effluent discharge reported to be within the $\mathrm{pH}$ limits of 5.5-9.5 [10]. The guideline ensures that wastewater treated is within the $\mathrm{pH}$ limits of neutral water, thus making it environmentally safe when discharged into the land or water bodies. The EPA standard for TSS removal from wastewater discharged varies across the globe, but the $\mathrm{pH}$ regulation is likely within the limits of the guidelines specified by other health and environmental regulation authorities such as the World Health Organization (WHO), Environmental Impact Assessment (EIA) and Nigeria International Standards (NIS) among others [4]; [10].

There are different treatment processes applied to enhance the removal of contaminants from wastewater, this includes reverse oxidation, which is been applied in recent times to remove bacterial from wastewater, adsorption, coagulation and flocculation [9]; [10]; and [23]. Most commonly sought-out treatment processes cut across coagulation and flocculation for the removal of turbidity and suspended solid from wastewater that contain significant amount of settle-able solids [6]; [7]. Coagulation and flocculation treatment is an important step towards eliminating suspended solids from wastewater to enhance the clarity of the industrial wastewater before its disposal [18].

However, the use of aluminum sulfate, also known as alum for water treatment processes has been in practice since ancient times. In recent times coag-flocculation treatment of wastewater involving the use of organic waste materials has proven to be more effective and efficient considering the environmental impacts of simulated inorganic compounds coupled with the costs of producing them [7]; [11] and [15]. Considering the fact that; inorganic coagulant sources are 
mostly corrosive, consumes much energy and are very expensive [5]; [9] and [17]. Organic coagulants have proven to be cheaper and environmentally friendly considering their hydrophilic nature [13]; [15], yet the challenge of using organic materials still remains that; fundamental background knowledge about their $\mathrm{pH}$ modifications and understanding of their interactions with the substrates in the waste medium is often scarce, or insufficient to infer the best chemical configuration for treating a specific effluent [5]; [16].

In the quest to use more environmentally friendly coagulants, reference [19] applied eggshell in treatment of vegetable oil industrial effluent. Their work proved an efficiency of $88.56 \%$ for eggshell. It went further to compare with fish-scale, another natural coagulant. The results showed that eggshell has better performance in acidic solutions. Furthermore, the works of [20] explored the use of eggshell in harvesting microalgae species. This shows the versatility of eggshell as it can be applied to different areas. In the study [20] it was observed that eggshells can act as an adsorbent, and also as a spontaneous coagulant to agglomerate the microalgae cells. The study concluded that the separation efficiency of microalgae biomass was over $99 \%$ at the optimal conditions. The optimal conditions are: $80 \mathrm{mg} / \mathrm{L}$ flocculants dose (eggshells), $150 \mathrm{r} / \mathrm{min}$ mixing rate, 20 min mixing time, 20 min settling time and $\mathrm{pH} 6$.

Another study conducted by [21] showed the use of eggshell as a coagulant aid to alum in the removal of dye from aqueous system. In the study, alum as a primary coagulant has a removal efficiency of $86 \%$ on the dye (Methylene blue). On the other hand, when combined with eggshell as a coagulant aid, the removal efficiency increased to $98 \%$ [21]. The finding above proves that eggshell can be used as a standalone coagulant as well as flocculants aid. In all cases mentioned, we can see the effectiveness and efficiency of eggshell. Not to mention the cost effectiveness and the friendly environmental impact.

To this end, the present work attests the efficacy of reused waste material (Eggshell) in the removal of TSS from cosmetic wastewater treatment at optimum conditions. The novelty of the present work verifies the threshold TSS removal efficiency of the organic material following two methods: Response Surface Methodology (RSM) and Systematic method of experimental predetermined optimal $\mathrm{pH}$, dosage and residual TSS $(\mathrm{g} / \mathrm{L})$. The objectives of the research also include the analyzing of the efficacy of Eggshell Coagulant (ESC) to satisfying the EPA pH standard for industrial wastewater discharge. Also; the threshold rate constant $\left(\mathrm{k}_{\mathrm{f}}\right)$ was evaluated following a predetermined TSS concentration of $40 \mathrm{~g} / \mathrm{L}$ and the rate constants $\left(\mathrm{k}_{\mathrm{m}}\right)$ for the $\mathrm{ABC}$ and ESC driven coag-flocculation reaction were also determined using the $2^{\text {nd }}$ order kinetics model for a maximum settling time of 30minutes. Thus; the efficacy of the organic material was ascertain by employing the criterion of comparing the results $\left(k_{m} \geq k_{f}\right)$ at the optimal points. The research was also aim at evaluating the efficacy of the re-used waste material based on a coag-flocculation operation cost analysis as a function to determine the clarification efficacy of ESC compared with ABC for the removal of TSS from cosmetic wastewater. 


\subsection{MATERIALS AND METHOD}

2.1 Materials: The wastewater sample was collected from the production site of Emos-Best Group of Industries Nigeria Limited. The organic coagulant samples were obtained from re-used waste material (Eggshell) as a gift from traders along Onitsha main Market, South Eastern Nigeria.

2.2 Preparation of the Coagulant: Eggshell samples weighing $5 \mathrm{~kg}$ were sun dried for about 3 weeks. The dried samples were crushed and ground to increase its surface area. They were then screened through 20 mesh sizes to obtain flour of finer particles which were collected in a container ready for use.

The eggshell coagulant sample (ESC) was characterized at Pymok Research Laboratory Nigeria Limited, Enugu. A proximate analysis was then carried out on the prepared organic coagulant following the method in reference [8], at Spring Board Research Laboratory Awka, Nigeria. The characterization and results of the analysis are presented in table 2. The conventional coagulant (ABC) used for this experiment consisted of $5 \mathrm{~kg}$ of Aluminum salt of industrial grade. It was bought from a chemical vendor; Kincel Excel Nigeria Limited. The Alum has the chemical formula: $\mathrm{Al}_{2}\left(\mathrm{SO}_{4}\right)_{3} .18 \mathrm{H}_{2} \mathrm{O}, \mathrm{MW}=666.42 \mathrm{~g} / \mathrm{mol}, 51-59 \% \mathrm{Al}_{2}\left(\mathrm{SO}_{4}\right)_{3} ;$ molecular weight $=$ $666.42 \mathrm{~g} / \mathrm{mol}$, consisting of $51-59 \% \mathrm{Al}_{2}\left(\mathrm{SO}_{4}\right)_{3}$, and $\mathrm{pH}(2.5-5.5)$. This was processed into powdered form to increase its surface area, and stored in a container ready for use.

2.3 Wastewater Analysis and Characterization: The industrial wastewater analysis and characterization was carried out at Halden Nigeria Limited, Port-Harcourt. The wastewater sampling and preservation was carried-out in accordance with the standard method of examination of wastewater handling [13]. The wastewater characterization was carried out immediately when samples arrived in the laboratory.

2.4 Procedure: The standard experimental procedure was conducted for the determination of the TSS $(\mathrm{g} / \mathrm{L})$ concentration following the coag-flocculation treatment of the wastewater.

The filtration apparatus was set up in the laboratory, and filter was inserted, de-ionized water was used to wet the filters. $250 \mathrm{ml}$ of the wastewater sample was poured into 5 conical flasks. The flasks were carefully labeled for proper identification. Each flask was placed on a magnetic stirrer, the $\mathrm{pH}$ of the samples were adjusted to; 2, 4, 6, 8 and 10 respectively using $0.1 \mathrm{M} \mathrm{H}_{2} \mathrm{SO}_{4}$ and $0.1 \mathrm{M} \mathrm{NaOH}$ just before dosing the coagulant. The doses of the organic coagulants ranging from $0.1 \mathrm{~g}$ to $0.5 \mathrm{~g}$ were measured out from the powdered ESC and added to each conical flask to form solutions. The TSS volumes of the samples were measured after placing the magnetic stirrer bar into the wastewater sampling bottle on the stirring unit. The stirring speed was maintained at $110 \mathrm{rpm}$ for 2 minutes after which the speed was reduced to $35 \mathrm{rpm}$. The stirrer was stopped after 20minutes to allow the solution to settle. 
The settling time was varied from 2, 4, 6, 8, 10, 20 and 30minutes respectively. During the settling period, $25 \mathrm{~cm}^{3}$ pipettes was used to withdraw samples from $2 \mathrm{~cm}$ depth of the conical flasks at constant settling time for each treated sample. The samples were placed on separate filters and continuous suction was exercised on the samples in the filters for about 3minutes until the volume were observed to slowed down the filtration process. The volume of the filtered was measured out in a graduated cylinder and recorded in liters $(\mathrm{L})$ on a bench sheet. The filters were then transferred into an oven set to $104^{\circ} \mathrm{C}$, and fired for an hour. The filters were then allowed to cool to room temperature. The samples in the filters were then weighed to the nearest $1.0 \mathrm{~g}$, and the corresponding masses in the weight check section were recorded. The oven dry mass (g) was also recorded for each sample analyzed, and was used in determining the initial concentration of the TSS of the sample in $\mathrm{g} / \mathrm{L}$.

The procedures used to determine the oven dry mass and mass of filter after drying was repeated for each treated sample of ABC and ESC respectively, and the results were tabulated. The values of the TSS concentration for each treated sample were evaluated mathematically to the nearest $0.1 \mathrm{~g} / \mathrm{L}$ applying equation 1 .

$$
\operatorname{TSS}\left(\mathrm{N}_{\mathrm{i}}\right)=\left[\frac{\mathrm{W}_{\mathrm{i}}-\mathrm{W}_{\mathrm{o}}}{\mathrm{V}}\right]
$$

Where: $\mathrm{W}_{\mathrm{i}}$ is the mass of filter + dried residue $(\mathrm{g}), \mathrm{W}_{\mathrm{o}}$ is the mass of filter or tare weight $(\mathrm{g})$ and $\mathrm{V}(\mathrm{L})$ is the volume of sample filtered.

The corresponding filtered volume and oven dry mass of each sample were measured and used in calculating the concentration of the suspended solid (TSS) particles of the wastewater samples. This was done before and after treatment with the measured doses of the coagulants ABC and ESC respectively. The corresponding values of the residual TSS $(\mathrm{g} / \mathrm{L})$ were determined using equation 2:

$$
\begin{array}{ll}
\text { Residual TSS }(\mathrm{g} / \mathrm{L})=\left[\mathrm{N}_{0}-\mathrm{N}_{\mathrm{i}}\right] & \text { Eq. } 2
\end{array}
$$

Where: $\mathrm{N}_{\mathrm{i}}$ is the final TSS volume $(\mathrm{g} / \mathrm{L})$ in the wastewater sample after coag-flocculation treatment with ABC and ESC respectively, and $\mathrm{N}_{0}$ is the initial TSS volume (g/L) before coagflocculation treatment.

The percentage TSS removal efficiency was calculated for each sample analyzed using:

$$
\% \mathrm{E}=\frac{\mathrm{N}_{0}-\mathrm{N}_{\mathrm{i}}}{\mathrm{N}_{0}} \times 100
$$

The concentrations of the total suspended particles of the wastewater were evaluated by a multiplying factor of 2.35 [14]. Where: $\mathrm{C}_{\mathrm{i}}$ represents the concentrations $(\mathrm{g} / \mathrm{L})$ of the colloidal particles causing turbidity in the wastewater sample.

$$
\mathrm{C}_{\mathrm{i}}=2.35 \times \mathrm{N}_{\mathrm{i}}
$$


2.5 Experimental Design and Analysis: The experiments were designed using two methods; Systematic method and the Central Composite Design (CCD) were selected for the ABC and ESC driven coag-flocculation optimization analysis.

The systematic method involved the use of established experimental predetermined optimum $\mathrm{pH}$, and dosage for ESC and $\mathrm{ABC}$ respectively. The systematic method employed the EPA standard $\mathrm{pH}$ limits between 5.5-9.5 [7]. This was used for determining the best $\mathrm{pH}$ that yields minima TSS residuals following $\mathrm{ESC}$ and $\mathrm{ABC}$ driven coag-flocculation treatment processes. Also an experimental predetermined residual TSS volume less than $40 \mathrm{~g} / \mathrm{L}$ ( TSS $\leq 40 \mathrm{~g} / \mathrm{L}$ ) was applied as a criterion to determine the optimal dosage $(\mathrm{g} / \mathrm{L})$ at settling time of 2, 4, 6, 10, 20 and 30minutes respectively for the ESC and $\mathrm{ABC}$ coag-flocculation treatment. This approach has been previously employed for the removal of dye component by adsorption and coag-flocculation reported in the work of reference [14].

The CCD selected with the RSM is an experimental design method used for building linear, quadratic, or cubic models for responses. It provides information about interactions among experimental variables; $\mathrm{pH}$, dosage and settling time within the range studied. This leads to a better knowledge of the process [ $8 \& 9]$. A process model establishing equations, describing the experimental results as a function of factors levels. The most common empirical models that fit the experimental data assume a linear, quadratic or cubic form. The final model equation is in the form below:

$$
\mathrm{Y}=\mathrm{b}_{0}+\mathrm{b}_{1} \mathrm{x}_{1}+\mathrm{b}_{2} \mathrm{x}_{2}+\mathrm{b}_{3} \mathrm{x}_{3}+\mathrm{b}_{12} \mathrm{x}_{1} \mathrm{x}_{2}+\text { experimental errors } \quad \text { Eq. } 5
$$

Where $\mathrm{Y}$ is the response total suspended solids (TSS) removal from the wastewater samples, and $b_{1}, b_{2}$, and $b_{12}$ etc are respective coefficients of the model equations developed to represent the interaction of the variables: dosage, $\mathrm{pH}$ and settling time for both the ABC and ESC driven coagflocculation process.

\subsection{RESULTS AND DISCUSSION}

The wastewater analysis was carried out to quantitatively and qualitatively account for the principal contaminants of the sample. The characteristics result from the analysis of the wastewater sample posted the Total Suspended Solids (TSS) record of $232 \mathrm{mg} / \mathrm{L}$, while the Total Dissolve Solids (TDS) content of $401 \mathrm{mg} / \mathrm{L}$ and 350NTU turbidity content was recorded for the sample. The biochemical oxygen demand (BOD) and chemical oxygen demand (COD) of the wastewater was measured to be less than $14 \mathrm{mg} / \mathrm{l}$ as presented in (Table 1), at $\mathrm{pH} 4.2$, this implies the wastewater is highly contaminated. Also the wastewater sample collected from the industrial facility has a low acidity of $6.02 \mathrm{mg} / \mathrm{L}$ with high alkalinity of $134 \mathrm{mg} / \mathrm{L}$. The results proved that the characteristic of the wastewater sample before the coag-flocculation treatment does not satisfy the EPA acceptable standards for wastewater discharge. The wastewater characteristics are presented in table 1 . 
3.1 Characterization of the Coagulant: The analysis on the organic coagulant shows that; powdered form of ESC contains very high proportions of protein and ash contents of recorded at $62 \%$ and $29 \%$ respectively. This is an indication of the structure of the organic material is hydrophilic [5]; with the possible presence of these compounds within the structure of ESC under certain conditions is been reported induce coagulation as shown in the works of references [19]; [20] and [21] respectively. The moderate percentages of carbohydrate reported as $3.13 \%$ and fat content at $5.54 \%$ as presented in (Table 2) indicated that; the organic coagulant/flocculants likely contain cellulose and fatty acid compounds capable of promoting floc formation as reported in the work of [19]. The result depicts potential evidence that the structure of the coagulants contain natural polymeric compounds capable of forming polyamine groups with the potential to form aggregates with particles in the water medium which can be removed by settling.

Table 1: Characteristics of the Cosmetics Wastewater

\begin{tabular}{|c|c|c|}
\hline WASTEWATER & METHODS USED FOR ANALYSIS & VALUES \\
\hline pH & Apha 4500-H & 4.2 \\
\hline Turbidity (NTU) & D1889 & 350 \\
\hline Total Dissolved Solids, $\mathrm{g} / \mathrm{L}$ & Apha 2540-C & 401 \\
\hline Total Suspended Solids, g/L & Apha 2540-C & 232 \\
\hline Acidity, mg/l & Astm D1067 & 6.02 \\
\hline Alkalinity, mg/l & Apha 2320-B & 134 \\
\hline Chemical Oxygen Demand (BOD) mg/l & Apha 5210-B & 4.10 \\
\hline Biological Oxygen Demand (COD) mg/l & Apha 5220-D & $<3.5$ \\
\hline Feacal Coliform MPN/100ml & Apha 9221B \& 9221C & \\
\hline Electrical Conductivity, s/cm & Apha 2510 & 804 \\
\hline Total Coliform MPN/100ml & Apha 9221B \& 9221C & \\
\hline Free Fatty Acid, mg/l & & $<1$ \\
\hline Hydroquinone, mg/l & & $<1$ \\
\hline TOTAL VIABLE COUNT, Cfu/ml & Apha 9221B \& 9221C & $4 \times 10^{2}$ \\
\hline Flourescent Dissovled Organic Matter (FDOM) & & Not Accounted \\
\hline Coloured Dissloved Orgamic Matter(CDOM) & & Not Accounted \\
\hline
\end{tabular}

Table 2: Characterization and Proximate Analysis of the Organic Coagulant

\begin{tabular}{lc}
\hline Constituents & Composition (\%) \\
\hline Protein & 62.30 \\
Carbohydrate & 3.13 \\
Ash & 28.9 \\
Fiber & 0.03 \\
Crude Protein & 4.2 \\
Moisture & 0.1 \\
Fat Content & 5.54 \\
\hline
\end{tabular}




\subsection{Experimental Predetermined Optimum pH and Dosage of Coag-Flocculation}

The optimum state for $\mathrm{pH}$ and dosage for coag-flocculation treatment of the cosmetics wastewater was determined by systematic method of experiments. In the course of this research' this criterion $(6 \leq \mathrm{pH} \leq 9)$ was used for the determination of the optimum $\mathrm{pH}$, while the dosages of coagulants that maintains minima residual TSS values $\leq 40 \mathrm{~g} / \mathrm{L}$ was applied as the criterion for determining the optimal dosages of $\mathrm{ABC}$ and $\mathrm{ESC}$ respectively.

The optimum $\mathrm{pH}$ was pre-determined as the $\mathrm{pH}$ value within the limits of 5.5 and 9.5 that yields the desired flocculation characteristics with minima TSS residuals, this was in accordance to the acceptable $\mathrm{pH}$ range recommended by the EPA as standard for wastewater discharge [10]. Tables 3-4; presents the experimental data following the ABC and ESC driven coag-flocculation treatments of the cosmetics wastewater at constant settling time of 30minutes. The data were recorded after treatments of the water with $\mathrm{ESC}$ and $\mathrm{ABC}$ respectively.

The results from experimental data presented in table 3 show that; the ESC driven coagflocculation treatment satisfied the EPA standards at $\mathrm{pH} 6$ and 8 respectively. Although at $\mathrm{pH} 6$ and $0.1 \mathrm{~g} / \mathrm{L}$ dosage of coagulant, ESC satisfied the criterion of the experimentally predetermined $\mathrm{pH}$ and minima residual TSS value of less than $40 \mathrm{~g} / \mathrm{L}$, but did not satisfy the minima residual TSS values $\leq 40 \mathrm{~g} / \mathrm{L}$ criterion at $\mathrm{pH} 8$. Hence we conclude by the systematic method that; experimental predetermined optimal $\mathrm{pH}$ and dosage of ESC are recorded as 6 and $0.2 \mathrm{~g} / \mathrm{L}$ which correspond to a minimum residual TSS value of $39 \mathrm{~g} / \mathrm{L}$. This implies TSS value of the wastewater was reduced from $232 \mathrm{~g} / \mathrm{L}$ to $39 \mathrm{~g} / \mathrm{L}$. Thus; $0.2 \mathrm{~g} / \mathrm{L}$ of ESC removed $193 \mathrm{~g} / \mathrm{L}$ of suspended solids from the cosmetics wastewater.

However from table 4, it can be observed that at $\mathrm{pH}$ values $6-8$, and dosages ranging from $0.1 \mathrm{~g} / \mathrm{L}$ through $0.5 \mathrm{~g} / \mathrm{L}, \mathrm{ABC}$ satisfies the criterion for the systematic method of experimental predetermined optimal $\mathrm{pH}$ and dosage. Hence, we can conclude from the experimental results presented in table 4; that the experimental predetermined the optimal $\mathrm{pH}$ and dosage for the $\mathrm{ABC}$ driven coag-flocculation plots: 8 and $0.1 \mathrm{~g} / \mathrm{L}$ at the settling time of 30 minutes respectively. This correspond to a minimal residual TSS value of $7 \mathrm{~g} / \mathrm{L}$ which yielded the best results that satisfies the EPA pH standards for wastewater discharge and the minima threshold of TSS value $\leq 40 \mathrm{~g} / \mathrm{L}$. Thus we can conclude from the results that $\mathrm{ABC}$ reduced the TSS value of the cosmetics waste water from $232 \mathrm{~g} / \mathrm{L}$ to $7 \mathrm{~g} / \mathrm{L}$ following the coag-flocculation treatment of the wastewater at the optimal points. Other areas of good performances of $\mathrm{ABC}$ were reported at $\mathrm{pH} 6$ and $0.1 \mathrm{~g} / \mathrm{L}$, and at $\mathrm{pH} 8$, and dosages ranging from $0.2 \mathrm{~g} / \mathrm{L}$ through $0.5 \mathrm{~g} / \mathrm{L}$ respectively.

The experimental data in (tables 3-4), confirms that; $\mathrm{pH} 2$ and $\mathrm{pH} 4$ respectively were not within the specified criterion $(6 \leq \mathrm{pH} \leq 9)$. Hence; were not significant for both the ABC and ESC driven coag-flocculation treatments, as such did not satisfy the EPA pH standards for wastewater discharge at these points. Although the ABC satisfies the criterion minima residual TSS values $\leq$ $40 \mathrm{~g} / \mathrm{L}$ at $\mathrm{pH} 10$. The $\mathrm{pH}$ elevation of the solution does not produce significant result to meet the EPA standards for industrial wastewater discharge. Hence the results produced were considerably 
far below optimum points for the $\mathrm{ABC}$ and $\mathrm{ESC}$ driven coag-flocculation treatments of the wastewater.

Thus, the experimental predetermined optimal conditions for the $\mathrm{ABC}$ coag-flocculation treatment of the industrial wastewater lies between dosage $(0.1 \mathrm{~g} / \mathrm{L}$ and $0.2 \mathrm{~g} / \mathrm{L})$ and $\mathrm{pH}(6$ and 8$)$ respectively as presented in (table 3-4). Thus there is a probable reason as to further confirm the efficacy of the $\mathrm{ABC}$ and ESC driven coag-flocculation following a cost remediation analysis. This tendency can help to reduce coagulant wastage and help in achieving better outputs at reduced time of experimental testing [14].

Table 3: Experimental Predetermined Optimum dosage and $\mathrm{pH}$ for $\mathrm{ABC}$ as a Function of the Residual Total Suspended Solids (TSS) for Cosmetic Wastewater according to EPA standard

\begin{tabular}{|c|c|c|c|c|c|c|c|c|c|}
\hline \multicolumn{10}{|c|}{ Dosage $(g / 1)$} \\
\hline pH & 0.1 & 0.2 & 0.3 & 0.4 & 0.5 & $\begin{array}{c}\text { Optimum } \\
\text { dosage } \\
\text { (g/L) }\end{array}$ & $\begin{array}{c}\text { Residual } \\
\text { TSS } \\
<40 \mathrm{~g} / \mathrm{L} \\
\end{array}$ & $\begin{array}{c}\text { Optimum } \\
\text { pH }\end{array}$ & $\begin{array}{c}\text { EPA/WHO } \\
\text { Standards } \\
5.5-9 \\
\end{array}$ \\
\hline \multicolumn{10}{|c|}{ RESIDUAL TOTAL SUSPENDED SOLIDS (TSS) AFTER 30 MINUTES SETTLING TIME } \\
\hline 2 & 51 & 67 & 68 & 72 & 56 & & $\begin{array}{c}\text { Not } \\
\text { Satisfied }\end{array}$ & & $\begin{array}{c}\text { Not } \\
\text { Satisfied }\end{array}$ \\
\hline 4 & 51 & 107 & 128 & 93 & 100 & & & & \\
\hline 6 & 40 & 81 & 114 & 44 & 100 & 0.1 & Satisfied & $\mathrm{pH} 6$ & Satisfied \\
\hline 8 & 7 & 14 & 13 & 9 & 33 & 0.1 & Satisfied & pH 8 & Satisfied \\
\hline 10 & 35 & 81 & 51 & 39 & 35 & $0.1,0.4,0.5$ & Satisfied & $\mathrm{pH} 10$ & $\begin{array}{c}\text { Not } \\
\text { Satisfied }\end{array}$ \\
\hline
\end{tabular}


Table 4: Experimental Optimum dosage and pH for ESC as a Function of the Residual Total Suspended Solids (TSS) for Cosmetic Wastewater according to EPA standard

\begin{tabular}{|c|c|c|c|c|c|c|c|c|c|}
\hline & \multicolumn{5}{|c|}{ Dosage $(\mathrm{g} / \mathrm{L})$} & \multirow[b]{2}{*}{$\begin{array}{c}\text { Optimum } \\
\text { dosage } \\
\text { (g/L) }\end{array}$} & \multirow[b]{2}{*}{$\begin{array}{c}\text { Residual } \\
\text { TSS } \\
<40 \mathrm{mg} / \mathrm{L} \\
\end{array}$} & \multirow[b]{2}{*}{$\begin{array}{c}\text { Optimum } \\
\text { pH }\end{array}$} & \multirow[b]{2}{*}{$\begin{array}{c}\text { EPA } \\
\text { Standards } \\
5.5-9\end{array}$} \\
\hline pH & 0.1 & 0.2 & 0.3 & 0.4 & 0.5 & & & & \\
\hline \multicolumn{10}{|c|}{ RESIDUAL TOTAL DISSOLVED SOLIDS (TSS) AFTER 3OMINUTES SETTLING TIME } \\
\hline 2 & 113 & 101 & 107 & 116 & 118 & & $\begin{array}{c}\text { Not } \\
\text { Satisfied }\end{array}$ & & $\begin{array}{c}\text { Not } \\
\text { Satisfied }\end{array}$ \\
\hline & & & & & & & & & \\
\hline 4 & 132 & 122 & 135 & 142 & 112 & & $\begin{array}{c}\text { Not } \\
\text { Satisfied }\end{array}$ & & $\begin{array}{c}\text { Not } \\
\text { Satisfied }\end{array}$ \\
\hline 6 & 84 & 39 & 55 & 94 & 74 & 0.2 & Satisfied & 6 & Satisfied \\
\hline & & & & & & & & & \\
\hline 8 & 124 & 137 & 132 & 153 & 119 & & $\begin{array}{c}\text { Not } \\
\text { Satisfied }\end{array}$ & 8 & Satisfied \\
\hline & & & & & & & & & \\
\hline 10 & 132 & 109 & 111 & 142 & 120 & & $\begin{array}{c}\text { Not } \\
\text { Satisfied }\end{array}$ & & $\begin{array}{c}\text { Not } \\
\text { Satisfied }\end{array}$ \\
\hline
\end{tabular}

\subsection{Response Surface Methodology (RSM) for Process Optimization and Analysis}

The ABC and ESC coag-flocculation process optimization following the treatments cosmetics wastewater was studied using Response Surface Methodology (RSM). The Central Composite Design (CCD) was selected with zero blocks and used to build the modified cubic models for both $\mathrm{ABC}$ and ESC driven coag-flocculation. The analysis was carried out for 20 experimental runs to accommodate more interactions of the experimental factors; dosage $(\mathrm{A}) \mathrm{g} / \mathrm{L}, \mathrm{pH}(\mathrm{B})$, and $\mathrm{C}$ (Settling time) in Minutes. The qualities of the cubic models were expressed by the coefficients of determination $\mathrm{R}^{2}$ values, and their statistical significance (P-values). The model adequacy was checked by the Fisher's (F-value) in the same program using the trial version of the Design Expert software version 12.0.

The modified cubic model terms that described the ESC and ABC driven coag-flocculation characteristics were evaluated using the P-value (Probability) with 95\% confidence level. Three dimensional surface plots and their respective contours were developed for ESC and ABC based on the effects of the three factors at two levels. The cubic model was selected at P-values less than 0.0500 indicating significant model terms. 
The analysis of variance (ANOVA) result plots coefficient of determination $\left(\mathrm{R}^{2}\right)$ value of 0.9983 with an adjusted $\left(\mathrm{R}^{2}\right)$ value of 0.9892 , these result shows reasonable agreement with the predicted $\mathrm{R}^{2}$ value of 0.9999 which are close to unity. These values were obtained at standard deviation of 4.08 for the ESC driven coag-flocculation. The result for the developed cubic model is presented in the ANOVA (table 5). Also, the plot of figure 1 shows the degree of fitness of the model terms for the ESC coag-flocculation, and confirms that; there's a very high correlation between the predicted values and the actual values of the factors on experimental responses. The correlation between the actual versus the predicted values of the response described in figure1 was obtained at an adequacy of precision of 35.607. It confirmed the validity of the cubic model used with the design of experiment. The Model Fisher's (F-value) of 109.80 implies the model is significant [11]; [12]. In this case $\mathrm{B}, \mathrm{C}, \mathrm{AC}, \mathrm{B}^{2}, \mathrm{ABC}, \mathrm{A}^{2} \mathrm{C}, \mathrm{AB}^{2}, \mathrm{AC}^{2}, \mathrm{~B}^{2} \mathrm{C}$ are significant model terms. The final equation for the cubic model developed following the central composite design (CCD) is given by equation 5 :

$$
\begin{gathered}
Y=10+35.41 B-46.59 C+4.87 A C+36.75 B^{2}+5.25 A B C-114.13 A^{2} C-97.5 A B^{2}+69.85 A^{2} C \\
-92.25 B^{2} C
\end{gathered}
$$

However, an adjusted $\left(\mathrm{R}^{2}\right)$ of 0.9999 was obtained for the cubic model that describes the ABC driven coag-flocculation process. This value is also in reasonable agreement with the correlation coefficient $\mathrm{R}^{2}$ (1.0) and the predicted $\mathrm{R}^{2}$ of 1.0. These values are also very close to unity and confirms adequacy of the cubic model terms. These results are presented in the ANOVA table 6. The Model F-value of 21164.51, obtained at a (probability) P-value of less than 0.05, with an adequacy of precision value of 424.8392, and a standard deviation of 0.5788 which implies the cubic model is significant. In this case; $\mathrm{B}, \mathrm{C}, \mathrm{AB}, \mathrm{AC}, \mathrm{BC}, \mathrm{A}^{2}, \mathrm{~B}^{2}, \mathrm{C}^{2}, \mathrm{ABC}, \mathrm{A}^{2} \mathrm{~B}, \mathrm{~A}^{2} \mathrm{C}, \mathrm{AB}^{2}$ are significant model terms. The final reduced cubic model equation relating the response residual TSS (Y)g/L and the interactions of the independent process variables Dosage (A), $\mathrm{pH}(\mathrm{B})$, and Settling time $(\mathrm{C})$ for $\mathrm{ABC}$ driven coag-flocculation is represented by equation 6 :

$$
\begin{array}{rr}
Y=141.3+212 B-53.9 C+38 A B-49.6 B C-53.2 A^{2}-78.7 B^{2}-25.6 C^{2}+215 A B C-48 A^{2} C \\
-25.77 A B^{2} & \text { Eqn. : } 6
\end{array}
$$

The reduced cubic models developed following the CCD produced a series of optimized solutions at various levels of the experimental factors ( $\mathrm{pH}$, Dosage, and Settling time) used to confirm minimization of response residual TSS $(\mathrm{g} / \mathrm{L})$. The optimal point were developed with the goal of keeping the factors (dosage and settling time) within the experimental region, while the $\mathrm{pH}$ levels were maintained within the limits of 6-8 in order to satisfy the EPA pH guidelines for industrial wastewater discharge. 
Table 5: Analysis of Variance for the Modified cubic model for ESC

\begin{tabular}{|c|c|c|c|c|c|c|}
\hline Source & Sum of Squares & df & Mean Square & F-value & p-value & \\
\hline Model & 29278.80 & 16 & 1829.92 & 109.80 & 0.0012 & Significant \\
\hline A-DOSAGE & 159.79 & 1 & 159.79 & 9.59 & 0.0534 & \\
\hline B-pH & 241.24 & 1 & 241.24 & 14.47 & 0.0319 & \\
\hline $\begin{array}{l}\text { C-SETTLING } \\
\text { TIME }\end{array}$ & 567.24 & 1 & 567.24 & 34.03 & 0.0100 & \\
\hline $\mathrm{AB}$ & 28.13 & 1 & 28.13 & 1.69 & 0.2848 & \\
\hline $\mathrm{AC}$ & 190.12 & 1 & 190.12 & 11.41 & 0.0432 & \\
\hline $\mathrm{BC}$ & 105.12 & 1 & 105.12 & 6.31 & 0.0868 & \\
\hline $\mathrm{A}^{2}$ & 3.52 & 1 & 3.52 & 0.2109 & 0.6773 & \\
\hline $\mathrm{B}^{2}$ & 1800.75 & 1 & 1800.75 & 108.04 & 0.0019 & \\
\hline $\mathrm{C}^{2}$ & 108.44 & 1 & 108.44 & 6.51 & 0.0839 & \\
\hline $\mathrm{ABC}$ & 253.13 & 1 & 253.13 & 15.19 & 0.0300 & \\
\hline $\mathrm{A}^{2} \mathrm{~B}$ & 163.89 & 1 & 163.89 & 9.83 & 0.0518 & \\
\hline $\mathrm{A}^{2} \mathrm{C}$ & 592.02 & 1 & 592.02 & 35.52 & 0.0094 & \\
\hline $\mathrm{AB}^{2}$ & 437.07 & 1 & 437.07 & 26.22 & 0.0144 & \\
\hline $\mathrm{AC}^{2}$ & 342.00 & 1 & 342.00 & 20.52 & 0.0201 & \\
\hline $\mathrm{B}^{2} \mathrm{C}$ & 366.02 & 1 & 366.02 & 21.96 & 0.0184 & \\
\hline $\mathrm{C}^{3}$ & 2.95 & 1 & 2.95 & 0.1770 & 0.7023 & \\
\hline Pure Error & 50.00 & 3 & 16.67 & & & \\
\hline Cor Total & 29328.80 & 19 & & & & \\
\hline
\end{tabular}

$\mathrm{R}^{2}=0.9983$, Adjusted $\mathrm{R}^{2}=0.9892$, Adequacy Precision $=35.607$, Predicted $\mathrm{R}^{2}=0.9999$, Mean $=$ 119.6 , \% C.V $=4.08$, Std Dev. $=3.41, \mathrm{~F}$-value $=109.80$.

Table 6: Analysis of Variance for the Modified cubic model for ABC

\begin{tabular}{|c|c|c|c|c|c|c|}
\hline Source & Sum of Squares & df & Mean Square & F-value & p-value & \\
\hline Model & 92171.46 & 13 & 7090.11 & 21164.51 & 0.0001 & Significant \\
\hline A-DOSAGE & 0.0115 & 1 & 0.0115 & 0.0342 & 0.8605 & \\
\hline B-pH & 10149.8 & 1 & 10149.8 & 30296.96 & $<0.0001$ & \\
\hline C-TIME & 4848.42 & 1 & 4848.42 & 14472.89 & $<0.0001$ & \\
\hline $\mathrm{AB}$ & 525.20 & 1 & 525.20 & 1567.5 & $<0.0001$ & \\
\hline $\mathrm{AC}$ & 262.34 & 1 & 262.34 & 783.11 & $<0.0001$ & \\
\hline $\mathrm{BC}$ & 105.12 & 1 & 105.12 & 1389.39 & $<0.0001$ & \\
\hline $\mathrm{A}^{2}$ & 1374.00 & 1 & 1374.00 & 4101.50 & $<0.0001$ & \\
\hline $\mathrm{B}^{2}$ & 609.73 & 1 & 609.73 & 1820.09 & $<0.0001$ & \\
\hline $\mathrm{C}^{2}$ & 548.73 & 1 & 548.73 & 1637.99 & $<0.0001$ & \\
\hline $\mathrm{ABC}$ & 637.33 & 1 & 637.33 & 1903.66 & $<0.0001$ & \\
\hline $\mathrm{A}^{2} \mathrm{~B}$ & 8717.16 & 1 & 8717.16 & 25722.87 & $<0.0001$ & \\
\hline $\mathrm{A}^{2} \mathrm{C}$ & 510.72 & 1 & 510.72 & 1524.53 & $<0.0001$ & \\
\hline $\mathrm{AB}^{2}$ & 56.28 & 1 & 56.28 & 168.01 & $<0.0001$ & \\
\hline Residuals & 1.68 & 5 & 0.3350 & & & \\
\hline Lack of Fit & 1.01 & 1 & 1.01 & 0.0697 & & Not Significant \\
\hline Pure Error & 0.6667 & 4 & 0.1667 & & & \\
\hline Cor Total & 98060.14 & 19 & & & & \\
\hline
\end{tabular}

$\mathrm{R}^{2}=1.0000$, Adjusted $\mathrm{R}^{2}=0.9999$, Adequacy Precision $=424839$, Predicted $\mathrm{R}^{2}=0.9999$, Mean $=$ 103.8, \% C.V=0.561, Std Dev. $=3.41, \mathrm{~F}$-value $=0.5788$. 


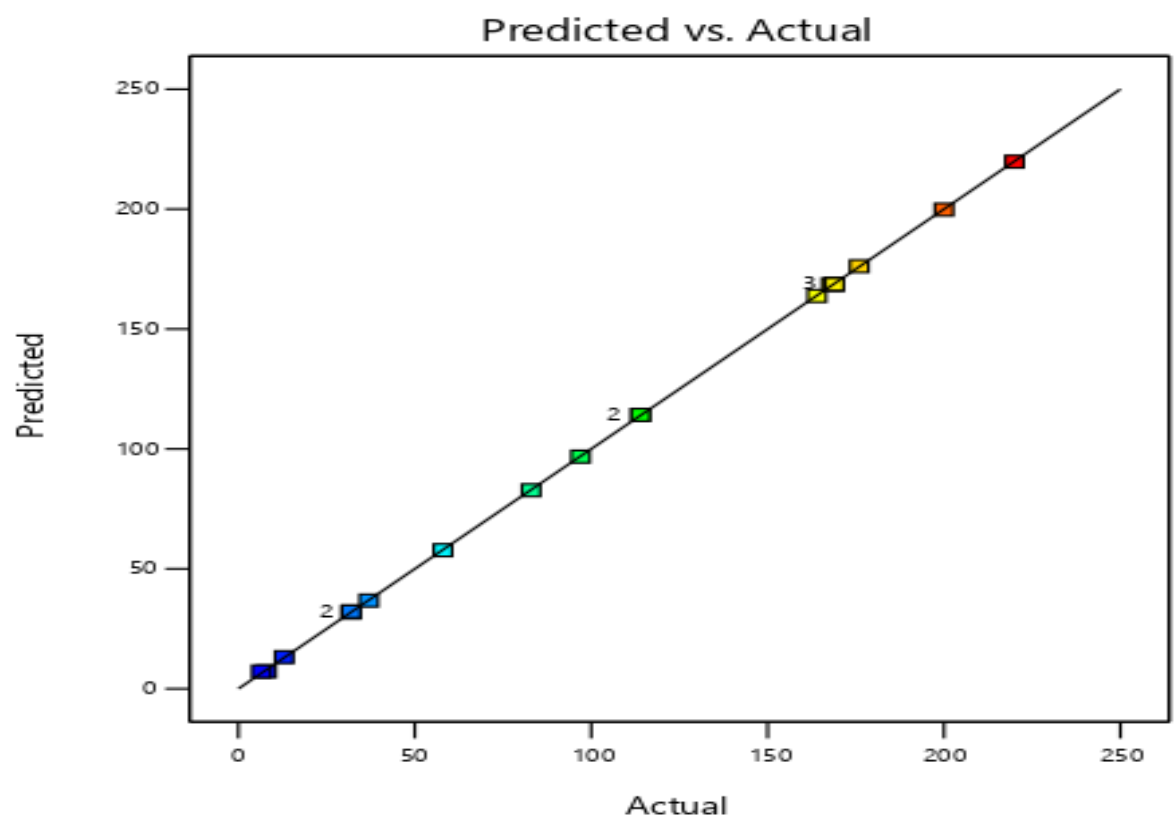

Figure 1: Plot Predicted of the Actual versus Predicted value of the Response

\subsection{Optimum Dosage and pH for ESC and ABC Coag-Flocculation Process}

The graphical representation of the 3-D surfaces shown in (figures 4-5) and contours (figure-8) and (figure-9) plot the solutions to the reduced cubic model (equations 5 and 6) in terms of the factors and responses derived from the $\mathrm{ABC}$ and $\mathrm{ESC}$ coag-flocculation optimization process. The optimal points for the ABC and ESC driven coag-flocculation are presented in the plots of figures 3 and 4. The 3D surfaces together with their respective contours for the ESC process optimization are presented in figures 4 and 9 while for $\mathrm{ABC}$ process optimization were presented in figures 5 and 8 respectively. The 3D surfaces and 2D contours can be used to confirm that the optimal points were located within the design boundaries and to investigate the mutual effect and interaction of the operational variables $(\mathrm{pH}$ and dosage) on the coag-flocculation treatment processes [13].

The results obtained with the RSM plots the optimal $\mathrm{pH}$, dosage, and settling time of $8,0.2 \mathrm{~g} / \mathrm{L}$, respectively and 23minutes settling time (figure-7) for the $\mathrm{ABC}$ driven coag-flocculation process. This corresponds to a residual TSS value of $6.46 \mathrm{~g} / \mathrm{L}$ which transcends to $97 \%$ removal efficiency of $\mathrm{ABC}$ in the solution. The result is represented in the ramp plot in (Figure-3), which was obtained for the optimal analysis at a desirability of 1.0. Also the 3D surface plot in (Figure-5) confirmed that the optimal points correspond to an output response of $6.46 \mathrm{~g} / \mathrm{L}$ of residual TSS, 
and that the lie within the design boundary. It can also be deduced from figure-5 that; at optimum operation, the TSS level in the wastewater sample was reduced from an initial $232 \mathrm{~g} / \mathrm{L}$ to $7 \mathrm{~g} / \mathrm{L}$ with $0.2 \mathrm{~g} / \mathrm{L}$ dosage of $\mathrm{ABC}$. This translates to $226 \mathrm{~g} / \mathrm{L}$ of TSS particles been removed from the wastewater at $\mathrm{pH} 8$.

Thus; from the evaluation of the optimal analysis, we can conclude that the result from the RSM is in agreement with the result obtained from the systematic method, and confirmed that the optimal $\mathrm{pH}$ ABC lies between $(6 \leq \mathrm{pH} \leq 9)$ which is in line with the EPA $\mathrm{pH}$ limit for industrial wastewater discharge. The response output of $6.46 \mathrm{~g} / \mathrm{L}$ shown in (figure 10) also satisfied the experimental predetermined criterion of residual TSS $\leq 4040 \mathrm{~g} / \mathrm{L}$ at the optimal points. The optimal settling time of 23 minutes shown in (figure-2) is in reasonable agreement with the maximum settling time of 30minutes in accordance with the experimental results presented in (Table 3).

The 2D contours (figures 8 and 10) show that; other areas of good performances lies between the $\mathrm{pH}$ elevation of 6 to 8, which plots residual TSS values between $40 \mathrm{~g} / \mathrm{L}$ and $7 \mathrm{~g} / \mathrm{L}$ corresponding to $0.1 \mathrm{~g} / \mathrm{L}$ and $0.2 \mathrm{~g} / \mathrm{L}$ dosages of $\mathrm{ABC}$ respectively. These results depict $\mathrm{pH}$ elevation of the wastewater towards a predominantly alkaline solution. It can also be infer from the result that the optimal dosage was less than $0.5 \mathrm{~g} / \mathrm{L}$ an indication that the coagulant aligns well with the wastewater particles to aggregate suspended solids present in the solution [9].

However, the optimum $\mathrm{pH}$, dosage and settling time of the ESC driven coag-flocculation were recorded as; $6,0.2 \mathrm{~g} / \mathrm{L}$ and 30 minutes respectively as presented in figure-3. These results were interpreted from the ramp plots in figure-3, obtained at a desirability of 1.0 at $95 \%$ confidence level. The optimal points translates to $84 \%$ TSS removal efficiency of the coagulant and transcends to a residual TSS value of $38 \mathrm{~g} / \mathrm{L}$ as shown in the $3 \mathrm{D}$ optimal plot ( figure-4) and contour (figure-9). The removal efficiency of ESC correspond to a TSS reduction from an initial $232 \mathrm{~g} / \mathrm{L}$ to $38 \mathrm{~g} / \mathrm{L}$ as recorded (figure-4) with an optimal dosage of $0.2 \mathrm{~g} / \mathrm{L}$ of ESC.

The optimal results obtained for the ESC driven coag-flocculation via the RSM were in agreement with the systematic method of predetermined optimum $\mathrm{pH}$, dosage, and Settling time of 6 , and $0.2 \mathrm{~g} / \mathrm{L}$ respectively at 30minutes settling time (figure-6) result obtained as presented in (Table 4). It can also be concluded from the optimal result of the ESC that; the optimal $\mathrm{pH}$ lies between $(6 \leq \mathrm{pH} \leq 8)$. This $\mathrm{pH}$ ensures the finish water is close to the $\mathrm{pH}$ of finish water in agreement with the EPA standards for industrial wastewater discharge.

The corresponding 3-D surface plots of figures 6-7 shows a considerable curvature in their contour curves; the implication is that two factors (dosage-settling time) were interdependent. The darker blue regions of the contours in (Figures 8-11) indicate higher quality of response where TSS values are minimized to residual TSS less than $40 \mathrm{~g} / \mathrm{L}$. Figure 6 posted, the best result is achieved at a dosage range of $0.1 \mathrm{~g} / \mathrm{L}-0.2 \mathrm{~g} / \mathrm{L}$ and settling time of $23-30$. The results recorded with the ABC driven coag-flocculation process (figure 8) also show that; other areas of good performances occurred at $\mathrm{pH} 6$ to 8 , settling time between the range of 23-30 minutes and $\mathrm{pH}$ 
range of 7-10 on the corresponding contour plots on figures 5. It shows that TSS value is minimized from $220 \mathrm{~g} / \mathrm{L}$ to $6.8 \mathrm{~g} / \mathrm{L}$ as dosage increases from $0.4 \mathrm{~g} / \mathrm{L}$ to $0.5 \mathrm{~g} / \mathrm{L}$. These areas of local minima were in agreement with the experimental predetermined optimum points reported in table-3 and table-4 respectively.
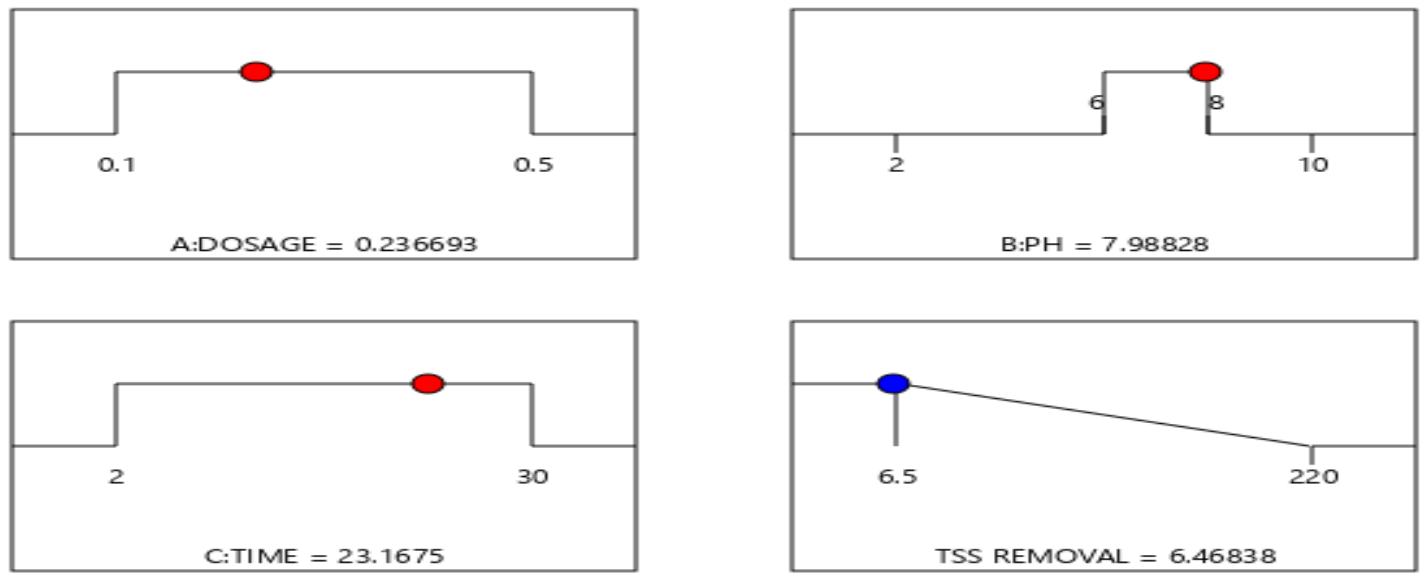

Desirability $=1.000$

Solution 1 out of 93

Figure 2: Desirability ramp plot for the ABC driven coag-flocculation Process
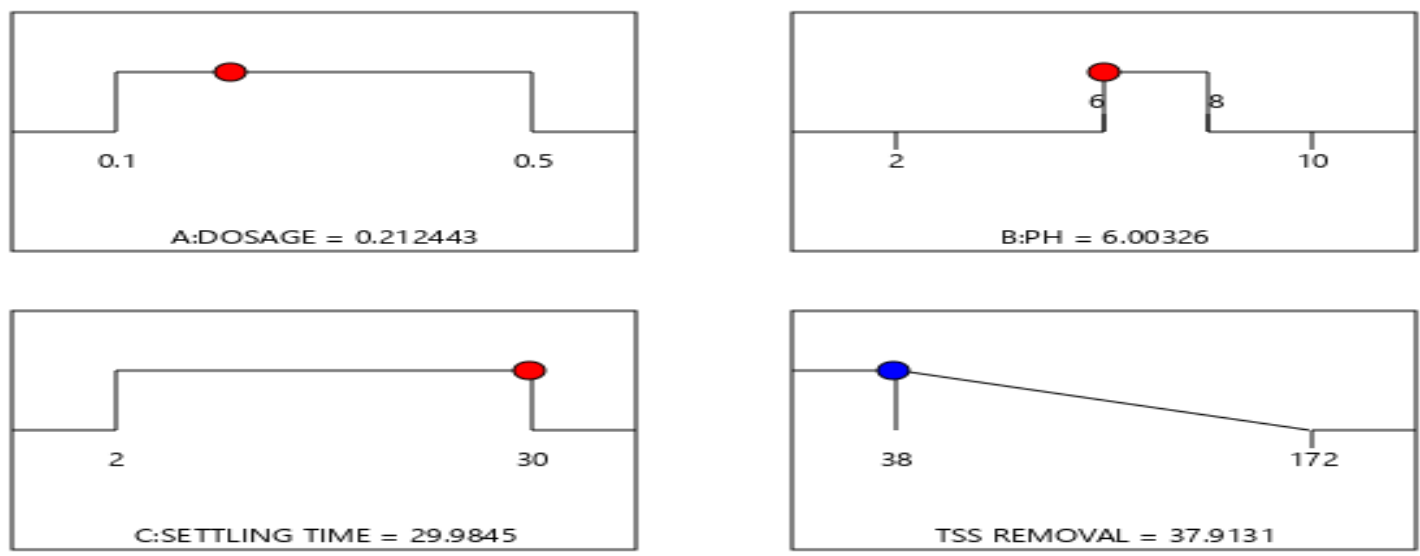

Desirability $=1.000$

Solution 1 out of 67

Figure 3: Desirability ramp plot for the ESC driven coag-flocculation Process 


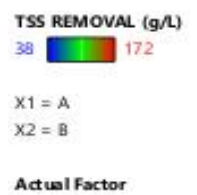

$C=29.9845$

Figure 4: 3D Surface Graph showing Residual TSS at optimum points for the ESC coag-flocculation

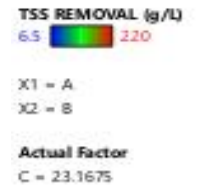

$c=23.1675$
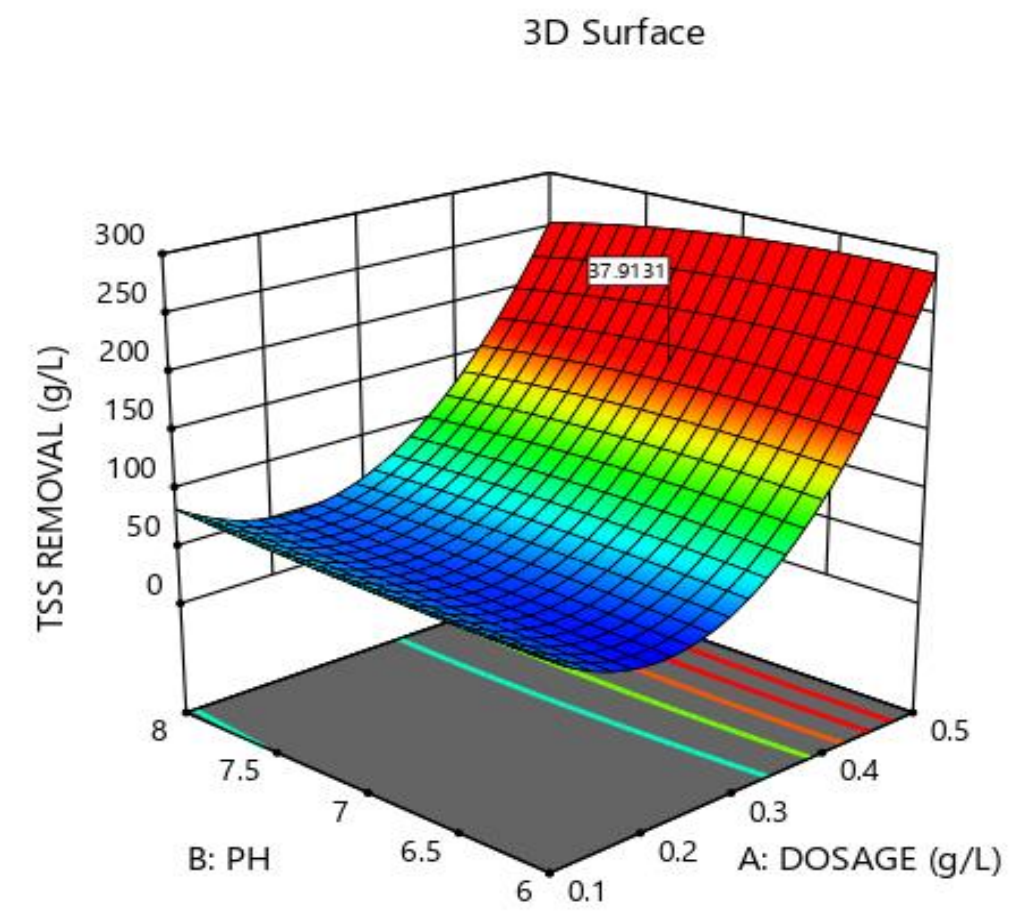


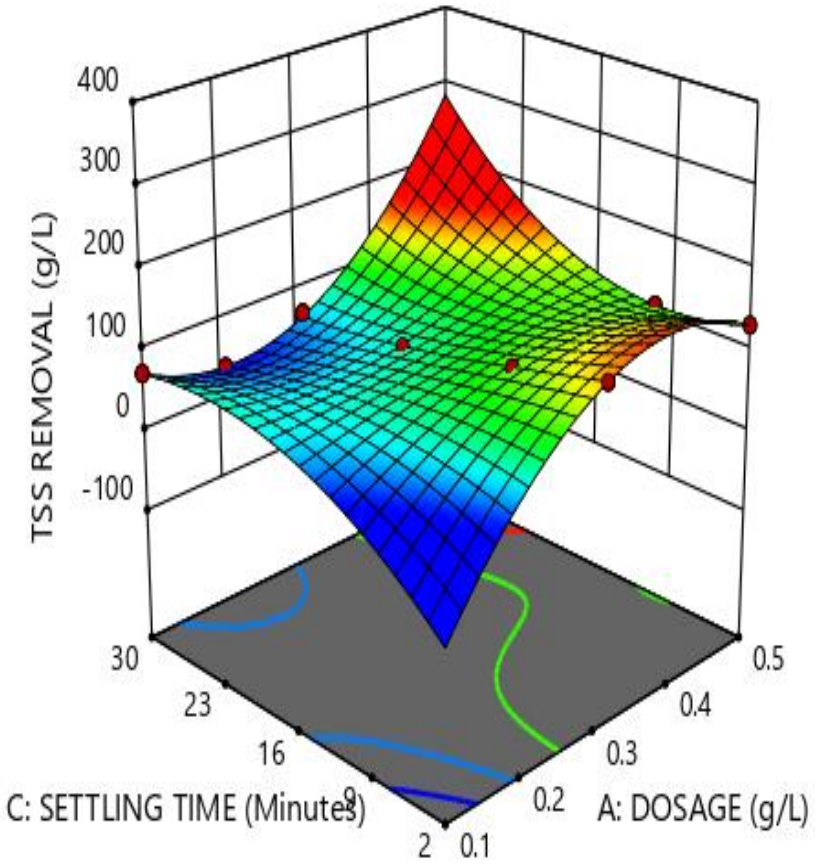

Figure 6: 3D Surface on Effect of settling time of ESC

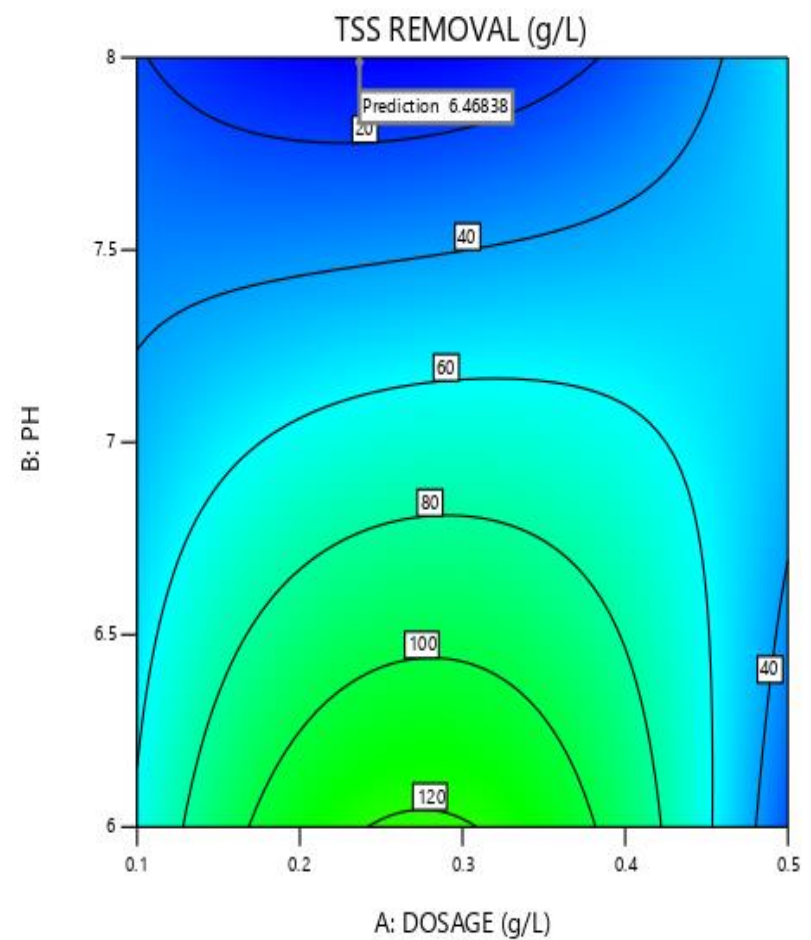

Figure 8: 2D Contour on Effect of Dosage of ABC

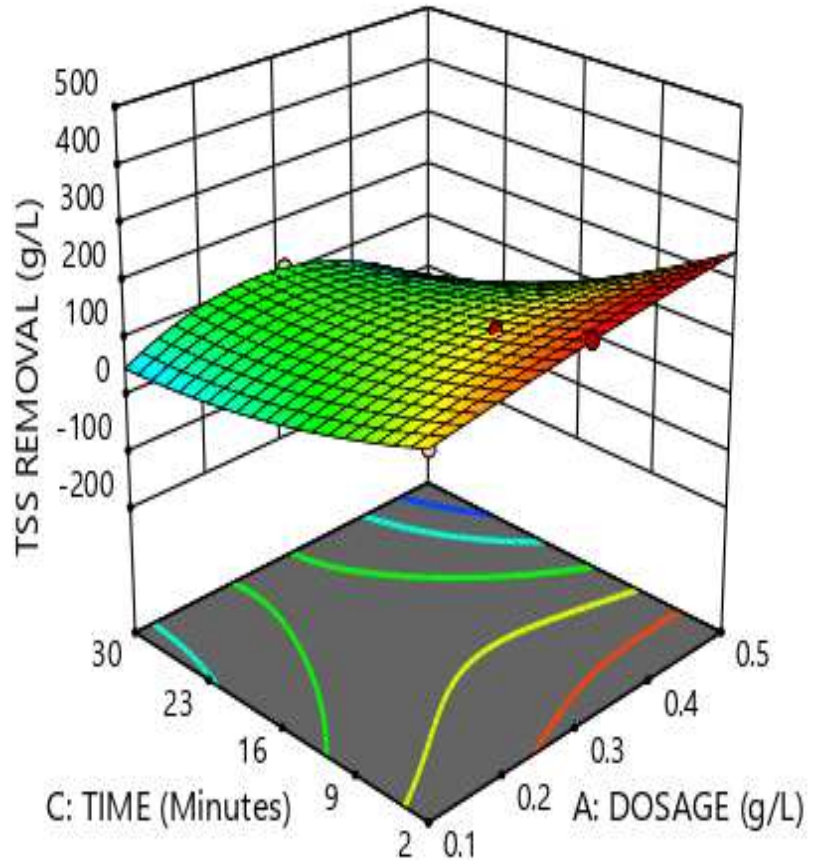

Figure 7: 3D Surface on Effect of settling time of ABC

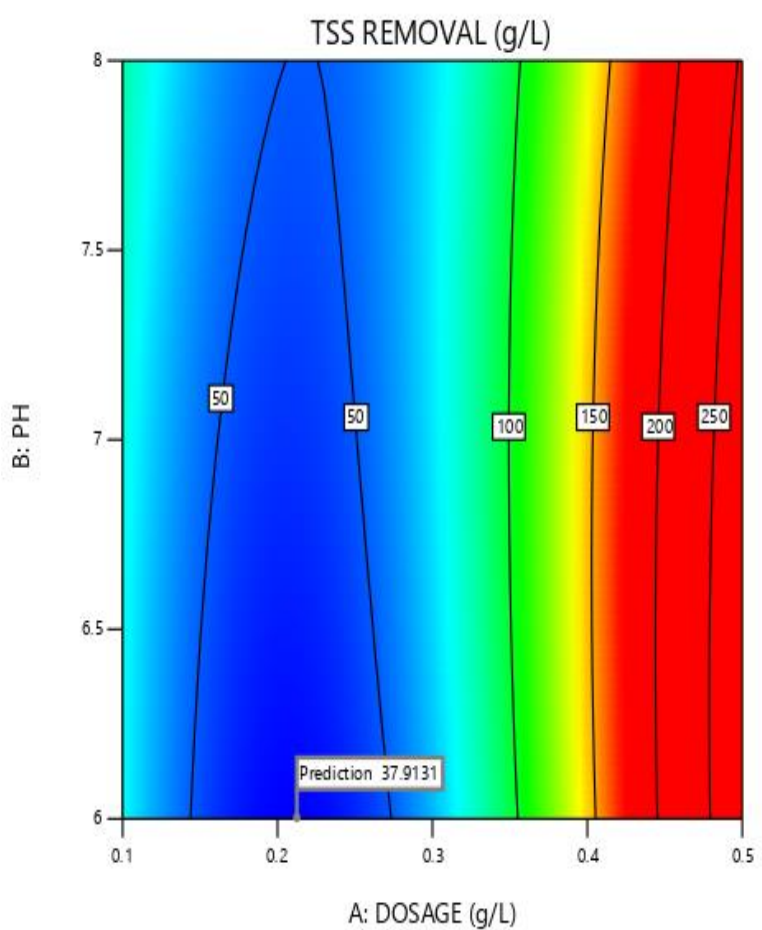

Figure 9: 2D Contour on Effect of Dosage of ESC 


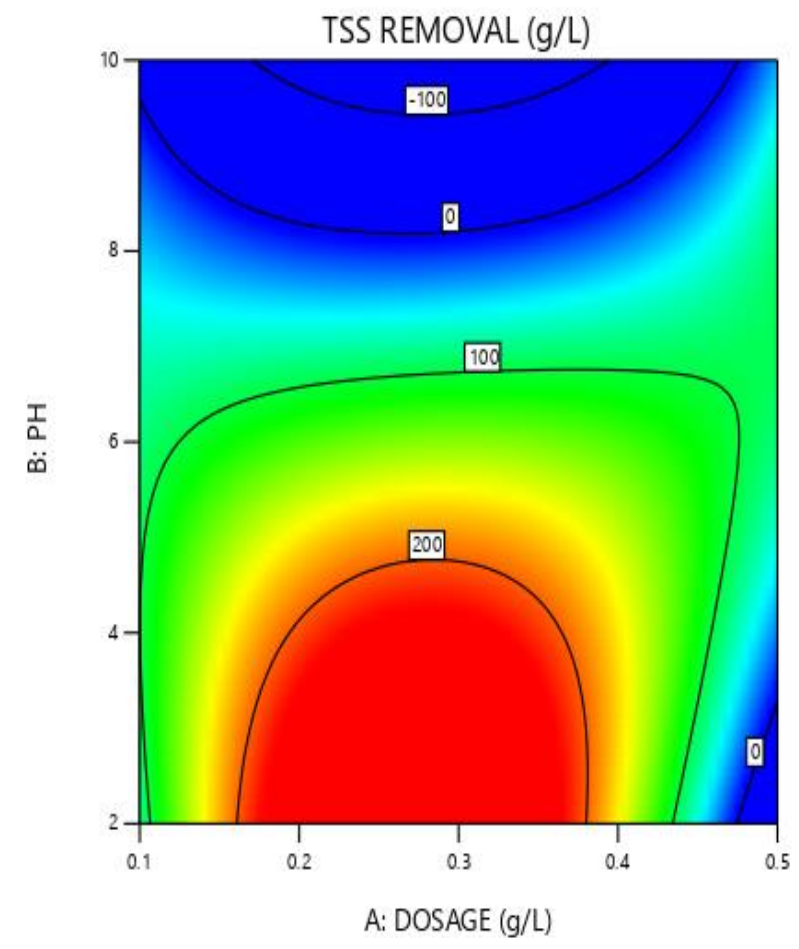

Figure 10: 3D Surface on Effect of $\mathrm{pH}$ of $\mathrm{ABC}$

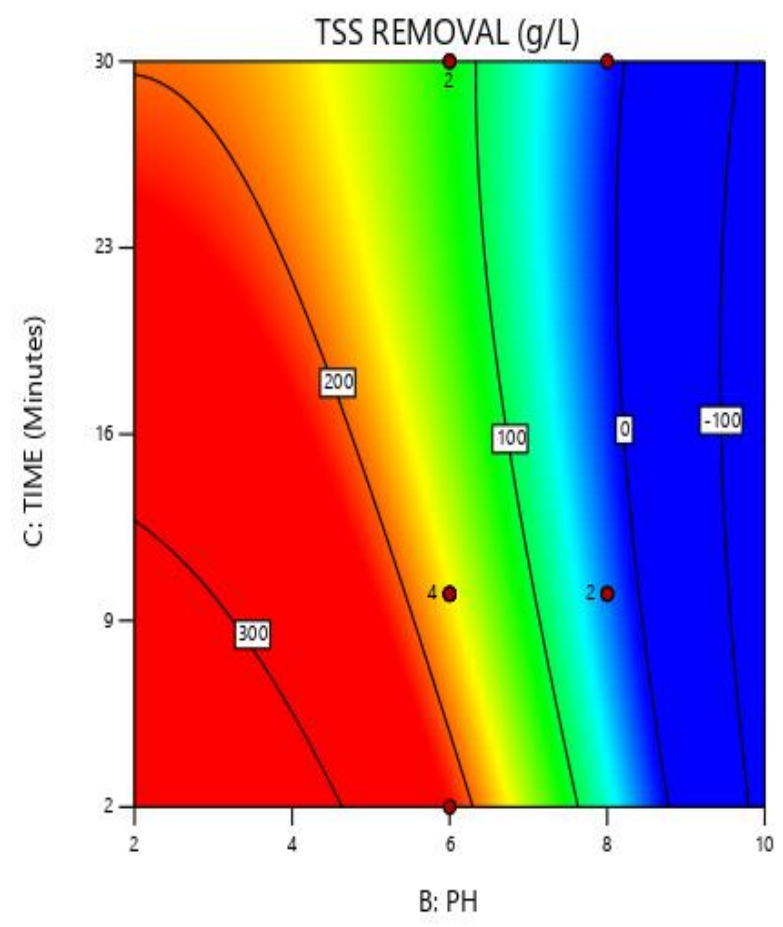

Figure 11: 3D Contour on Effect of pH on ESC

\subsection{The Coag-Flocculation Kinetics of ABC and ESC at Constant Settling-time}

The kinetics parameters which included the rate constants, order of reaction and the rate equations were developed following the analogies of the kinetic models of equation 3 through equation 9. However in real practice, empirical evidence shows that: $(0 \leq \alpha \leq 2)$ [13]. Kinetics model derivations can be deduced based on the kinetics dependency of coag-flocculation characteristics of BFB on concentration of TSS particles with time thus, the rate equation can be expressed as follows:

$$
-\mathrm{r}_{\mathrm{A}}=\mathrm{k}_{\mathrm{n}} \mathrm{C}_{\mathrm{i}}^{\mathrm{n}}
$$

\section{Eqn .7}

Where: $-\mathrm{r}_{\mathrm{A}}$ is the rate of Coag-flocculation, $\mathrm{K}$ : is the rate constant (L/g-min) for the nth-order coag-flocculation, $\mathrm{C}_{\mathrm{i}}$ : Concentrations of Particles $(\mathrm{g} / \mathrm{L})$ and $\mathrm{n}$-th: is the order of the Coagflocculation reactions.

Based on equation 7 , the first-order $(n=1)$ rate of coag-flocculation kinetics model at varying concentrations and reaction time $(t)$ is given by:

$$
\begin{aligned}
& -\mathrm{r}_{\mathrm{A}}=\frac{\mathrm{dC}_{\mathrm{i}}}{\mathrm{dt}}=\mathrm{KC}_{\mathrm{i}} \\
& \int \frac{\mathrm{dC}_{\mathrm{i}}}{\mathrm{C}_{\mathrm{i}}}=\mathrm{K}_{1} \int \mathrm{dt}
\end{aligned}
$$


Integrating both sides of equation 9 we obtained equation 10 :

$$
\operatorname{InC}_{\mathrm{i}}=\mathrm{K}_{1} \mathrm{t}-\mathrm{InC}_{0}
$$

Eqn .10

Most cases, the second order kinetics $(\mathrm{n}=2)$ holds for the coag-flocculation treatments of wastewater following the use of organic coagulants as reported in the works of reference [14]. Where the initial concentration of the suspended particles in the medium before coag-flocculation treatment is represented by: $\mathrm{C}_{0}$ and $\mathrm{C}_{\mathrm{i}}$ : represents the concentrations of the particles after the coag-flocculation treatment and $\mathrm{K}_{2}$ is the constant for the rate of second-order coag-flocculation reaction.

The $2^{\text {nd }}$ order kinetics model follows from equation 7 , such that:

$$
\begin{array}{ll}
\mathrm{r}_{\mathrm{A}}=\mathrm{k}_{2} \mathrm{C}_{\mathrm{i}}^{2}=\frac{\mathrm{dC}_{\mathrm{i}}^{2}}{\mathrm{dt}} & \text { Eqn .11 } \\
\frac{1}{\mathrm{C}_{\mathrm{i}}}=\mathrm{K}_{2} \mathrm{t}+\frac{1}{\mathrm{C}_{0}} & \text { Integrating both sides of equation 11, we arrived at: } \\
& \text { Eqn } .12
\end{array}
$$

Using $K_{2}$ as the references for $K_{f}$ and $K_{m}$, we arrive at equation 11:

$$
\mathrm{K}_{\mathrm{f}}=\mathrm{K}_{\mathrm{C}}=\left[\frac{\frac{1}{\mathrm{C}_{\mathrm{i}}}-\frac{1}{\mathrm{C}_{0}}}{\mathrm{t}}\right]
$$

Where $\mathrm{t}$ is the time (minutes), $\mathrm{K}_{\mathrm{m}}$ : is the rate constant for the 2nd-order coag-flocculation treatment of the wastewater at optimum conditions and $\left(\mathrm{K}_{\mathrm{f}}\right)$ is the threshold constant following the experimental TSS $<40 \mathrm{~g} / \mathrm{L}$ criterion.

The values of the rate constants $\left(\mathrm{K}_{\mathrm{m}}\right)$ for $\mathrm{ABC}$ at optimum $\mathrm{pH}$ of 8, and $\mathrm{ESC}$ at optimum $\mathrm{pH}$ of 6 were evaluated following equation 11. The threshold coag-flocculation constant $\mathrm{K}_{\mathrm{f}}$ was also calculated following equation 11 , where $C_{0}=232 \mathrm{~g} / \mathrm{L}$ corresponding to the initial value of TSS particle of the wastewater before coag-flocculation treatment, at time $(t=30$ minutes $)$ and $\left(C_{i}=\right.$ $40 \mathrm{~g} / \mathrm{L}$ ) corresponding to the experimental predetermined threshold value of residual TSS particle concentration after coag-flocculation treatment. The value of the threshold constant for the experimental predetermined following the criterion TSS $<40 \mathrm{~g} / \mathrm{L}$, thus; $C_{i}=40 \mathrm{~g} / \mathrm{L}$ was calculated to be equal to; $1.06 \times 10^{-2} \mathrm{~L} / \mathrm{g} \cdot \mathrm{min}$.

The values of the coag-flocculation rate constants were deduced for ESC and ABC respectively from equation 13. The results show that; at $\mathrm{pH} 8$, the values of coag-flocculation rate constants $\left(\mathrm{K}_{\mathrm{m}}\right)$ decreased from $3.27 \times 10^{-5} \mathrm{~L} / \mathrm{g} \cdot \mathrm{min}$ to $5.83 \times 10^{-5} \mathrm{~L} / \mathrm{g} \cdot \mathrm{min}$ as dosages of ESC increased consistently from $0.1 \mathrm{~g} / \mathrm{L}$ through $0.4 \mathrm{~g} / \mathrm{L}$ respectively.

The value of the rate constant then increased to $5.83 \times 10^{-5} \mathrm{~L} / \mathrm{g}$ min at $0.5 \mathrm{~g} / \mathrm{L}$ dosage of ESC. At $\mathrm{pH} 6$, the values of the rate constants $\mathrm{k}_{\mathrm{m}}$ following the ESC driven coag-flocculation increased 
from $1.09 \times 10^{-4} \mathrm{~L} / \mathrm{g} \cdot \mathrm{min}$ to $3.46 \times 10^{-4} \mathrm{~L} / \mathrm{g} \cdot \mathrm{min}$ as the dosage increased from $0.1 \mathrm{~g} / \mathrm{L}$ to $0.2 \mathrm{~g} / \mathrm{L}$. This trend was not consistent with dosages from $0.3 \mathrm{~g} / \mathrm{L}$ to $0.5 \mathrm{~g} / \mathrm{L}$, where the values of the constants were found to decrease from $1.97 \times 10^{-4} \mathrm{~L} / \mathrm{g} \cdot \mathrm{min}$ to $1.31 \times 10^{-4} \mathrm{~L} / \mathrm{g} \cdot \mathrm{min}$. From the values of rate constants obtained, we can conclude that the ESC kinetics rate constants decreases intermittently as the $\mathrm{pH}$ of the solution increased from 6 to 8 . The highest value of $\mathrm{k}_{\mathrm{m}}=$ $1.97 \times 10^{-4} \mathrm{~L} / \mathrm{g} \cdot \mathrm{min}$ was obtained at the optimum $\mathrm{pH} 6$, and dosage of $0.2 \mathrm{~g} / \mathrm{L}$, which was consistent with the optimal $\mathrm{pH}$ and dosage. It was also observed that; at elevated $\mathrm{pH} \geq 8$ resulted to low rate constants which corresponds to poor quality of the finish water, while at depression $\mathrm{pH} \leq 8$ plots higher values of rate constants which correspond to better performances. We concluded that ESC performed best at optimum $\mathrm{pH} \mathrm{6}$, at this point, the coagulants aligned well with the particles in the water sufficiently enough to induced coagulation. However, poor performance at $\mathrm{pH}$ elevation to 8 of ESC was predominantly due to the presence of excess alkalinity of the solution despite increasing the dosage of the organic material. We reasoned that the coagulation characteristics of the protein contents of ESC were suppressed by the dissolution of the fiber and fat content of ESC in solution. Also we reasoned that; the exhaustive protonation of wastewater particles by the functional groups present in ESC were not sufficient enough to induce coagulation beyond $\mathrm{pH}$ 6, thus at elevated $\mathrm{pH}$ ESC requires additional alkalinity to cause floc formation.

The results following the $\mathrm{ABC}$ driven coag-flocculation treatments show values of the kinetics rate constants $\mathrm{k}_{\mathrm{m}}$ decrease from $1.97 \times 10^{-3} \mathrm{~L} / \mathrm{g} \cdot \mathrm{min}$ to $3.69 \times 10^{-4} \mathrm{~L} / \mathrm{g} \cdot \mathrm{min}$ as dosage increase from $0.1 \mathrm{~g} / \mathrm{L}$ to $0.5 \mathrm{~g} / \mathrm{L}$ at $\mathrm{pH}$ 8. Also at $\mathrm{pH} 6$, the values of the kinetics rate constants also decreased from $3.06 \times 10^{-4} \mathrm{~L} / \mathrm{g} \cdot \mathrm{min}$ to $8.1 \times 10^{-5} \mathrm{~L} / \mathrm{g} \cdot \mathrm{min}$ as dosage of Alum were increased from $0.1 \mathrm{~g} / \mathrm{L}$ to $0.5 \mathrm{~g} / \mathrm{L}$. The maximum value of rate constant was obtained at the optimum $\mathrm{pH} 8$ and a dosage of $0.1 \mathrm{~g} / \mathrm{L}$.

The conclusions drawn from the coag-flocculation kinetics are such that the values of $\mathrm{K}_{\mathrm{m}}$ have direct bearing on the implementation of ESC and ABC to water treatment [14]. The criterion employed to determine the clarification efficacy of ESC compared with ABC at optimum conditions were acknowledged where the coagulants satisfied the EPA standard for wastewater discharge following equation 12 :

$$
\mathrm{K}_{\mathrm{m}} \geq \mathrm{K}_{\mathrm{f}}
$$

Eqn. 12

The plot of figures 11-12 shows the results for the efficacy of the organic coagulant following the criterion specified in equation 12; the coag-flocculation rate constants $\left(\mathrm{K}_{\mathrm{m}}\right)$ obtained for the ESC and $\mathrm{ABC}$ driven coag-flocculation at optimum $\mathrm{pH}$, dosage and constant settling time of 30 minutes were compared with the threshold coag-flocculation rate constant $\left(\mathrm{K}_{\mathrm{f}}\right)$.

The plot of figure 12 shows that; at the optimal dosage of $0.2 \mathrm{~g} / \mathrm{L}$ and at $\mathrm{pH} 6$, eggshell coagulant surpassed both the threshold point. The figure also plot that the rate constant value of ESC was higher when compared to that of $\mathrm{ABC}$. This confirms that; at optimum $\mathrm{pH}$ of $6,0.2 \mathrm{~g} / \mathrm{L}$ of the reused organic material (eggshell) was most effective than any applicable dosages of conventional 
alum in the removal of TSS from the industrial wastewater, as such Alum is not suitable at $\mathrm{pH}$ depression to 6 most especially when the alkalinity of the solution is considerably and the acidity is low. We can also concluded that the protein, ash, carbohydrate contents and moisture present in the structure of the organic material as reported in the proximate analysis (table 2) aligned well with the particles of the wastewater causing them to floc into aggregates, and that the finish water is stable at the optimal condition.

The plot in figure 13 shows that $0.1 \mathrm{~g} / \mathrm{L}$ dosage of $\mathrm{ABC}$ exceeded the threshold points with an exceptionally higher rate value compared to ESC at optimum $\mathrm{pH} 8$ coag-flocculation conditions. We conclude from the plot that Alum is most effective at a $\mathrm{pH}$ elevation to 8; this implies that $\mathrm{ABC}$ satisfied the EPA $\mathrm{pH}$ standards for wastewater discharge at a predominantly alkaline solution, this was likely due to the presence of high hydroxyl ions present in sufficient quantity which was responsible for high alkalinity of the solution, thus alum was sufficient enough to reducing the TSS value in wastewater to minima of $6 \mathrm{~g} / \mathrm{L}$. This was by far below the experimental predetermined threshold value of $40 \mathrm{~g} / \mathrm{L}$. Hence, its higher value of rate constant above the threshold constant indicates best performance. As such we concluded that for the ABC driven coag-flocculation, the hydrolysis terminated at $\mathrm{pH} 8$ with a critical TSS value corresponding to 97\% removal efficiency.

We reasoned that; at this elevated $\mathrm{pH}$; ESC was suppressed probably by exhaustive protonation of the functional groups this was probably due to the high alkalinity of the wastewater. Thus, the ESC driven coag-flocculation requires additional alkalinity to induce floc characteristics since coag-flocculation did not occur as desired.

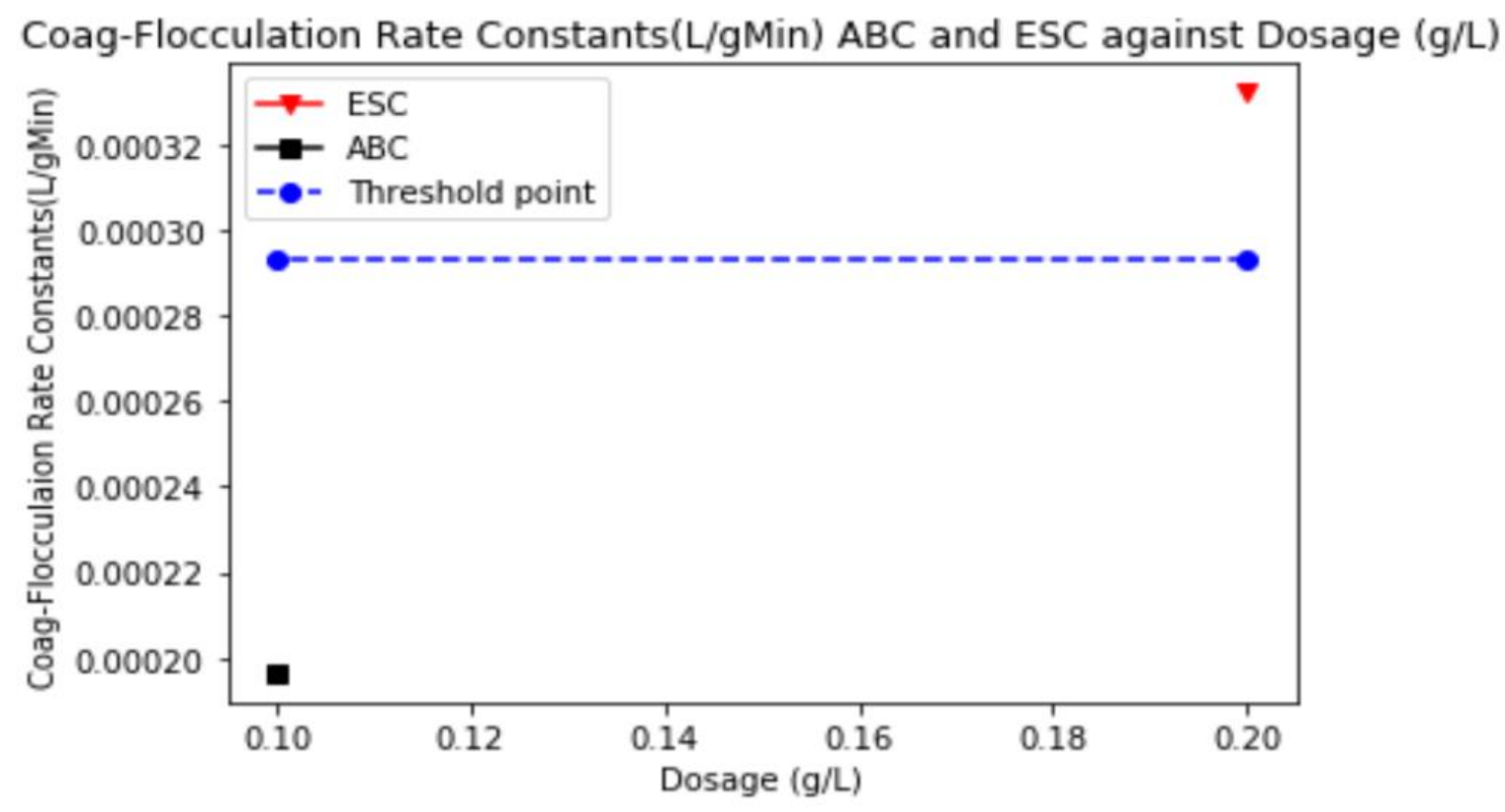

Figure 12: The threshold coag-flocculation rate constant as a point for evaluation factor to compare the efficacy of ESC and ABC at optimum conditions 


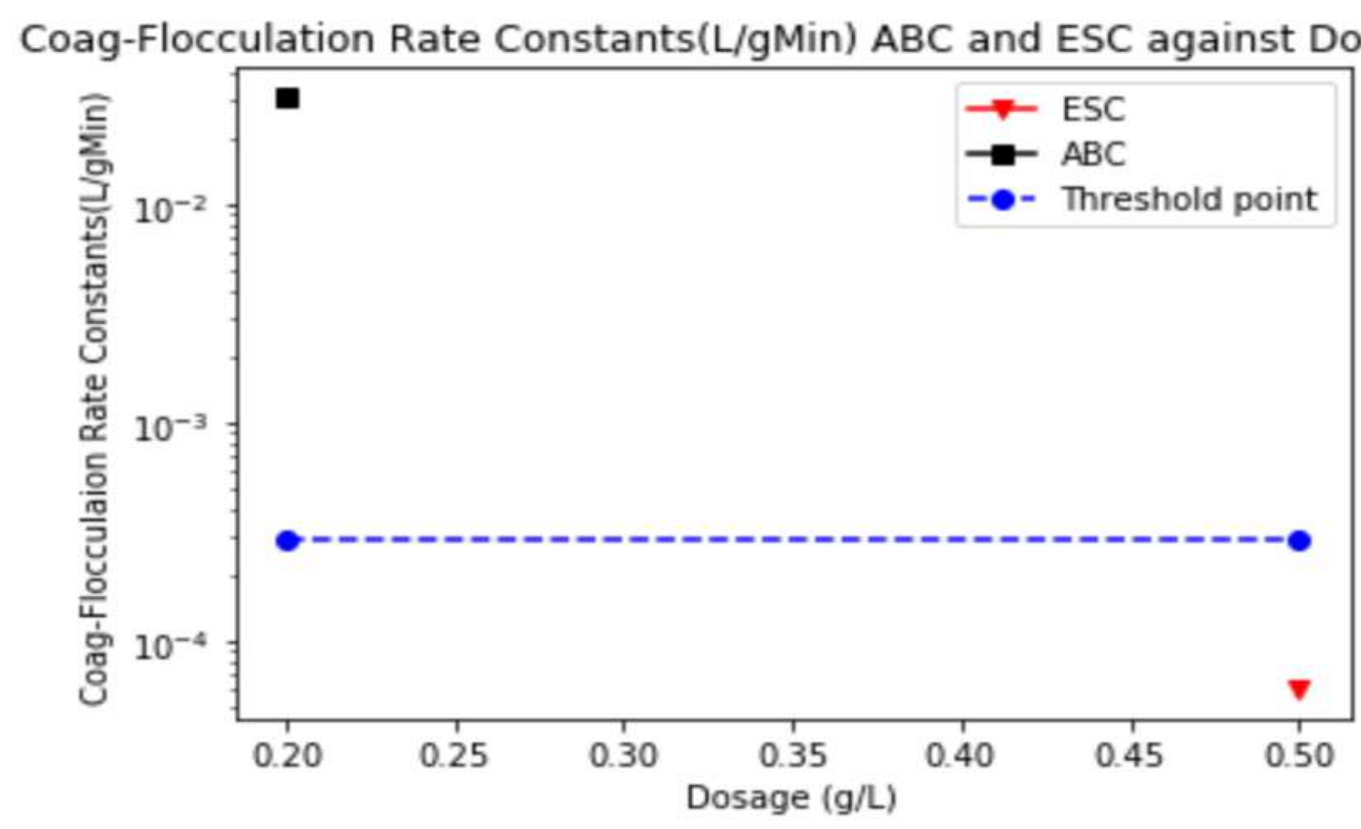

Figure 13: The threshold coag-flocculation rate constant as a point for evaluation factor to compare the efficacy of ESC and ABC at optimum conditions

\subsection{Comparisons of the Efficacy of ESC in other medium}

To summarize the efficacy study of ESC for the removal of TSS from cosmetics wastewater, we will compare the results from this study with those obtained from the research of other authors referenced in this work. Table 7 below gives a summary of the comparison. We can deduce from table 7 that; the removal efficiency of ESC was obtained at a pH less than or equal to 6 [19-20] irrespective of the medium applied. The results in table 7 confirmed the optimum $\mathrm{pH}$ obtained for the ESC driven coag-flocculation for present study. The table further emphasizes the effectiveness of ESC occur at minimal dosage the results were also in reasonable agreement with the result from the present study. The differences in the removal efficiencies were very minimal of this was due to the differences in characteristics of medium to which ESC was applied. The can conclude from the table that; the results of the removal efficiencies of ESC, with their corresponding optimal results obtained in references [19]; [20] and [21], describes ESC to be a viable coagulant/flocculants aid. Furthermore, the maximum removal efficiency was obtained when used as a coagulant aid to alum. Also organic material has also been proven to have very high removal efficiency when used in a microalgae environment. The cost benefit analysis will further elaborate the efficiency and importance of ESC coagulant in the treatment of cosmetic wastewater systems. 
Table 7: Comparison of ESC Removal Efficiency at Optimal Conditions

\begin{tabular}{|c|c|c|c|c|}
\hline Parameters & $\begin{array}{c}\text { ESC } \\
\text { (Present Study) }\end{array}$ & $\begin{array}{c}\text { ESC } \\
\text { (Reference 19) }\end{array}$ & $\begin{array}{c}\text { ESC } \\
\text { (Reference 20) }\end{array}$ & $\begin{array}{c}\text { ESC +Alum } \\
\text { (Reference21) }\end{array}$ \\
\hline Medium & $\begin{array}{c}\text { Cosmetic } \\
\text { Industrial } \\
\text { Wastewater }\end{array}$ & $\begin{array}{c}\text { Vegetable Oil } \\
\text { Industrial } \\
\text { Effluent }\end{array}$ & $\begin{array}{c}\text { Microalgae } \\
\text { Species }\end{array}$ & $\begin{array}{c}\text { Dye Aqueous } \\
\text { System }\end{array}$ \\
\hline $\begin{array}{c}\text { Removal efficiency } \\
(\%)\end{array}$ & 85 & 88.56 & 99 & 98 \\
\hline $\begin{array}{c}\text { Dosage of eggshell } \\
(\mathrm{g} / \mathrm{L})\end{array}$ & 0.2 & 0.5 & 0.08 & 0.07 \\
\hline $\mathrm{pH}(-)$ & 6 & 4 & 6 & 6 \\
\hline Settling Time (mins) & 30 & 40 & 20 & - \\
\hline
\end{tabular}

\subsection{Cost Benefits Remediation Analysis of Coag-flocculation}

The objectives of the study were to test and recommend ESC as a natural coagulant/flocculants aid to be used as substitute or as hybrids with other conventional chemicals for the coagflocculation treatments of industrial wastewater. The $6 \mathrm{~g} / \mathrm{L}$ TSS residual value corresponding to a removal efficiency of $97 \%$ achieved for the treatment of cosmetic wastewater with an optimal dosage of $0.1 \mathrm{~g} / \mathrm{L}$ at $\mathrm{pH}$ value of 8 for ABC. However, $38 \mathrm{~g} / \mathrm{L}$ residual TSS corresponding to $85 \%$ removal efficiency was reported for the ESC driven coag-flocculation treatment of the cosmetic wastewater at $\mathrm{pH} 6$, with $0.2 \mathrm{~g} / \mathrm{L}$ dosage. The major difference in the efficacies of the coagulants will be based on the results from the production of coagulants, the cost remediation analysis for the coag-flocculation treatment of the industrial wastewater will include:

1. Material including transportation cost to the sites

2. Energy Cost

3. Labor (Personnel cost)

The present cost analysis took into account the market prices as well as provided by vendors across the world. The raw materials take into account multiple market prices for other $(A B C)$ coagulants used specifically for TSS removal from wastewater. The summary of the cost estimate for both coagulants is summarized in figure 14 .

Using the Energy consumption $\mathrm{E}_{\mathrm{c}}$ equation to evaluate the energy cost;

$$
E_{C}=P_{D}\left(a \times t \times C_{C}\right)
$$


Where $\mathrm{P}_{\mathrm{D}}$ : is the power consumed by the device in $(\mathrm{KW})$, a: is the load factor, $\mathrm{t}$ : is time in $(\mathrm{Hr})$ and $\mathrm{C}_{\mathrm{C}}$ : is the cost per consumption. The values of $\mathrm{a}=1$ when the equipment was used at full load module, and $\mathrm{a}=0.5$ for half load mode

The cost of electricity per KWH (Kilo-watt Hour) for this study is $0.107 \$ / \mathrm{KWH}$ based on the average price in Nigeria in 2020. This includes all components of electricity bills like cost for power, distribution and taxes calculated as an average annual level of electricity consumption. This price was retrieved from the Benin Electrical Distribution Company; estimated price of $1 \mathrm{kWH}$ in Nigeria [22]. Equation 13 was used to calculate the total energy cost requirement for this project and estimated to be 2.48USD.

In terms of cost analysis, we concluded that; it is more economical to use the ESC as opposed to the conventional ABC, since ESC is a readily available waste material that can be sourced for. It encourages waste management through recycling of eggshell waste. This project supports and meets the requirement of EPA with the $\mathrm{pH}$ range showing less acidity. It also supports waste management as both cosmetic wastewater and eggshell waste have been converted to economical use, saving cost as well as protecting the environment. Figure 14 gives a better illustration of the cost benefits analysis, comparing the cost of using ESC and ABC as coagulants for removal of TSS for cosmetics wastewater.

\section{$\mathrm{ABC}$ and ESC Cost Chart}

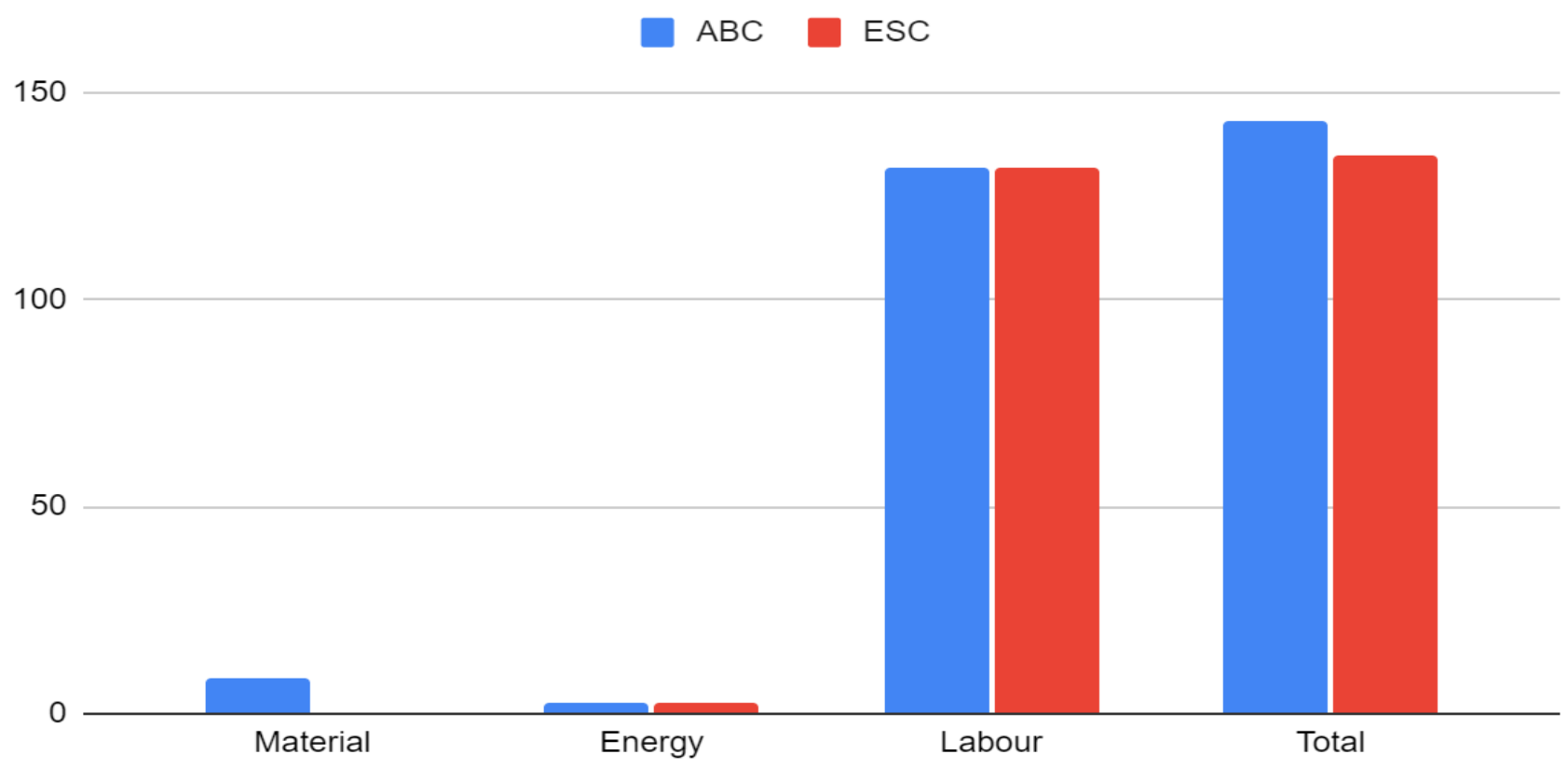

Figure 14: Cost Remediation Chart to compare the ABC and ESC coag-flocculation Treatments 


\section{CONCLUSION}

The coag-flocculation treatment of cosmetic wastewater using eggshell and Aluminum sulphate was successfully conducted at $110 \mathrm{rpm}$ and the conclusions drawn were such that: the coagflocculation rate constants has a direct bearing towards evaluating the efficacy of both organic and inorganic coagulants, where higher rate constants corresponds to better performances of the coagulants. Eggshell was proven to be efficient for the removal of Total Suspended Particles (TSS) from cosmetic wastewater than alum coagulant at optimum $\mathrm{pH}$ 6. The organic material functioned effectively at best $0.2 \mathrm{~g} / \mathrm{L}$ as a coagulant/flocculants aid for the removal of TSS from the wastewater. The output of eggshell was proven to have satisfied the Environmental Protection Agency (EPA) standard for industrial wastewater discharge at minimum dosage, and the $\mathrm{pH}$ of the finish water was close to neutral at 30minutes settling time. Hence it was proven at the optimal dosage that the eggshell driven coag-flocculation prevented wastage of coagulants, reduce cost of service, and the finish water was neither corrosive nor scaling at the optimum condition. The effectiveness of Aluminum sulphate was also found to occur with a minimal dosage. It effectively removed TSS from the industrial wastewater to a minimal. It preserved the alkalinity of the industrial wastewater. We conclude further from the cost remediation analysis conducted on the coag-flocculation treatment process that it is more economical to treat wastewater with hydrophilic eggshell than Alum in cases where the alkalinity of the wastewater is very high or greater than $100 \mathrm{mg} / \mathrm{L}$ with low acidity characteristics or less than $20 \mathrm{mg} / \mathrm{L}$. 


\section{DECLARATION}

\section{Ethics and Approval}

Not applicable to this research work.

\section{Consent for Publication}

Not applicable to this research work.

\section{Availability of Data and Material}

The authors declare that all data used for the research analysis were obtained from experimental research work carried out in the laboratory. The majority of the experimental data are available within the manuscript in the Result and Discussion section. However, the authors are willing to provide additional data to further scientific research on this field prior to request. The data for this research work have are available with the corresponding author.

\section{Competing Interest}

The authors declare there are no conflict of interests in the publication of the manuscript, and approve for the original copy manuscript to be published.

\section{Financial Disclosure}

This research is supported by the Nnamdi Azikiwe University Awka, and Emos-Best Industrial group Nigeria Limited. The authors acknowledged that no external funding was received for this research work. The authors were directly involved in the funding of the research work at various levels.

\section{Author Contributions}

The manuscript was written through contributions of all authors: L. C. Okpala carried out the supervision of the wastewater and coagulants analysis. L. C. Okpala and P. E. Ovuoraye conducted the laboratory experiments including the measurements of the TSS concentrations of the wastewater before and after coag-flocculation treatments, and measurements of the dosages of coagulants. P. E Ovuoraye prepared the design matrices used for the development of the experimental runs, analyzed the data used in experimental analysis, conducted the optimization of the coag-flocculation process, and developed the kinetics model used to evaluate the coagflocculation rate constants. G. F. Nwokocha and P. E Ovuoraye evaluated the cost remediation analysis, sorted out all software permission used for the graphical analysis and G. F. Nwokocha was also involved massively with P. E. Ovuoraye in the overall preparation of the manuscripts. V. $\mathrm{N}$ Ugonabo $(\mathrm{PhD})$ conceptualized the research work, and supervised the whole project including the process of obtaining the Coagulants and Wastewater from the remediation site. He examined the floc characteristics and helped in preparation and development of the Coagulants. V. N Ugonabo $(\mathrm{PhD})$ also aided the collection of the wastewater sample from the industry. V .N 
Ugonabo and P. E. Ovuoraye, carried-out the development of the kinetics model calculations and the examination of the efficacy analysis for the coagulants. All authors have read and agreed to the published version of the manuscript.

\section{Acknowledgments}

Our acknowledgement goes to Emos-Best Group of Industries Nigeria Limited for allowing us to secure the wastewater used for this research work. Also to Halden Nigeria Limited Port-Harcourt, River State, for their contribution in providing the wastewater analysis. Our acknowledgement also goes to the lecturers and staff Chemical Engineering department, of the Nnamdi Azikiwe University for their immense support and encouragement. Finally to Pymotech Research Centre, Enugu State, for their support in the proximate analysis.

\section{Software Permission}

The trial version of the software Design Experts version12.0 used in this research work were obtained prior to permissions from the vendor. 


\section{REFERENCE}

1. Bello Lukman Abidemi, Omoboye Adekunle, Abiola Temitope, Oyetade Joshua, and Ayeola Rachael: "Treatment Technology of Wastewater from Cosmetic Industry a Review." International Journal of Chemical and Bio-molecular Sciences. (2019): Vol. 4:4: pp 69-80

2. Sample PDF documentation on "Global Cosmetics Products Market Top Country Data" (2020) : http://www.360marketupdates.comsample/12884489 , http:www.wfmj.com

3. Google documents New York. Published by Zion market research New York, (2018). http://www.zionmarketresearch.com/sample/cosmetic-products-market.

4. WHO/UNEP, GEMS. “Global freshwater quality”. Oxford, Alden Press, 1989

5. Tetteh Emmanuel Kweinor; and Sudesh Rathilal "Application of Organic Coagulants in Water and Wastewater Treatment." Inter-open. (2019): Issue 845556: http//dxdio:10.5772/Inter-open.84556

6. Nguyen V.N.T; Qiming J; Yu Tan; Pong Nguyen; and San-Lang W; "Coagulation of Chitin Production Wastewater from Shrimps Scraps with By-product from Chitosan and Chemical Coagulant Polymers." MDPI Academic Open Access Publishing. 126072020 (2020): 20

7. John Bratby "Coagulation and Flocculation with emphasis on Water and Wastewater Treatment" Uplands Press Ltd. Publishers of Filtration \& Separations" magazines. Croydon CR, England. 1980. Pp253-1277.

8. Ajala E. O, Eleta O. A. A; Ajala M. A; and Oyeniyi S. K. "Characterization and Evaluation of Chicken Eggshell For use as Bio-Resources." Journal of Engineering Technology. 14-1 (2018): Pp. 26-40.

9. Clesceri L. S., Greenberg A. E. and Eaton A.D., "Standard Methods for the Examination of water and wastewater". $20^{\text {th }}$ Edition. ApHA. USA.

10. EPA guidelines for water quality-based decisions" The TMDL Process Doc. 1991; No. EPA 440/4-91-001

11. Goldini, H; Dargahi, A; Mohammadi, M; Hosseini Ahagh, M; Mohammadi, S; Jalilian, Z. "Application of Response Surface Methodology for the Optimization of Ammonia Nitrogen Removal from Aqueous Solutions Using Powdered Activated Carbon”. Res. J. Environ. Sci. (2017), 11, 36-47.

12. Ponnusamy, S. K; Subramaniam, R; "Process Optimization Studies of Congo red dye adsorption onto Cashew-nut using Response Surface Methodology”. Int. J. Ind. Chem. 2013, 11, 4, 17.

13. Menkiti M.C; Nnaji C; and Onukwuli O. D. "Coag-flocculation Kinetics and Functional Parameters Response of Periwinkle Shell Coagulant (PSC) to $\mathrm{pH}$ Variation in Organic Rich Coal Effluent." Journal of Natural Science. (2009): Pp 1-18.

14. Nnaji P.C, Okoye .C.C and Umeuzuegbu J.U. "Efficiency of Luffa Cylindrica and Muccuna Sloaneai Seeds in Dye Removal: A New Approach." WSN Journal. 2392-2192 (2020): Pp 184-201. 
15. Mao X; Guo N; and Sun J. "Cleaner Production Guide of Chito/ Chitin Oligosaccharides and its Monomer. In Oligosaccharides of Chitin and Chitosan, Bio-manufacture And Applications." Zhao L. Ed. Springer Singapore. 126072020 (2019): 107-127.

16. Goldini, H; Dargahi, A; Mohammadi, M; Hosseini Ahagh, M; Mohammadi, S; Jalilian, Z. "Application of Response Surface Methodology for the Optimization of Ammonia Nitrogen Removal from Aqueous Solutions Using Powdered Activated Carbon”. Res. J. Environ. Sci. (2017), 11, 36-47.

17. Google Material http://www.wioa.org.au/conference_papers/09_vic/documents/Sean Doyle poster.pdf

18. Ogemdi Kingsley, Iwuozor. "Prospects and Challenges of using Coagulation and Flocculation Method in Treatment of Effluents." Advance Journals of Chemistry: (2019): 2(2): 105-127. DOI: 10.29088/SAMI/AJCA.2019.2.105127

19. Okey-Onyesolu1 C. F., Okoye .C .C, Ude .C .N, Onukwuli .O .D and Achugbu .O .E. "Performance of Natural Coagulants in the Treatment of Vegetable Oil Industrial Effluent” Asian Journal of Advanced Research and Reports: (2020); 12(1): 12-21, Article no. AJARR.58220

20. Hee Jeong Choi "Effect of eggshells for the harvesting of microalgae species" Biotechnology \& Biotechnological Equipment, (2015), Vol. 29: Issue 4, 666-672, DOI:10.1080/13102818.2015.1031177

21. Adelagun R. O. A., Ngana O. C. and Ezekiel E. "Evaluation of Egg Shell as a Coagulant Aid in Dye Removal From Aqueous System" FUW: Trends in Science \& Technology Journal e-ISSN: 24085162; p-ISSN: 20485170; October, 2016 Vol. 1 No. 2 PP 591 - 594

22. New tariff rate and customers classification (BEDC) Electricity-Tariff. February (2016): Google material. www.bedcpower.com/new-electricitytariff-rate-2,

23. Afzal Husain Khan; Nadeem A. Khan; Sirajuddin Ahmed; Aastha Dhingra; Chandra Pratap Singh; Saif Ullah Khan; Ali Akbar Mohammadi; Fazlollah Changani; Mahmood Yousefi; Shamshad Alam; Sergij Vambol; Viola Vambol; Anwar Khursheed; Imran Ali "Application of advanced oxidation processes followed by different treatment technologies for hospital wastewater treatment" Elsevier BV Journal of Cleaner Production, (2020) ISSN: 0959-6526, Vol: 269, Page: 122-411 
Figures

TSS REMOVAL

Color points by value of

TSS REMOVAL:

$6.5 \square 220$

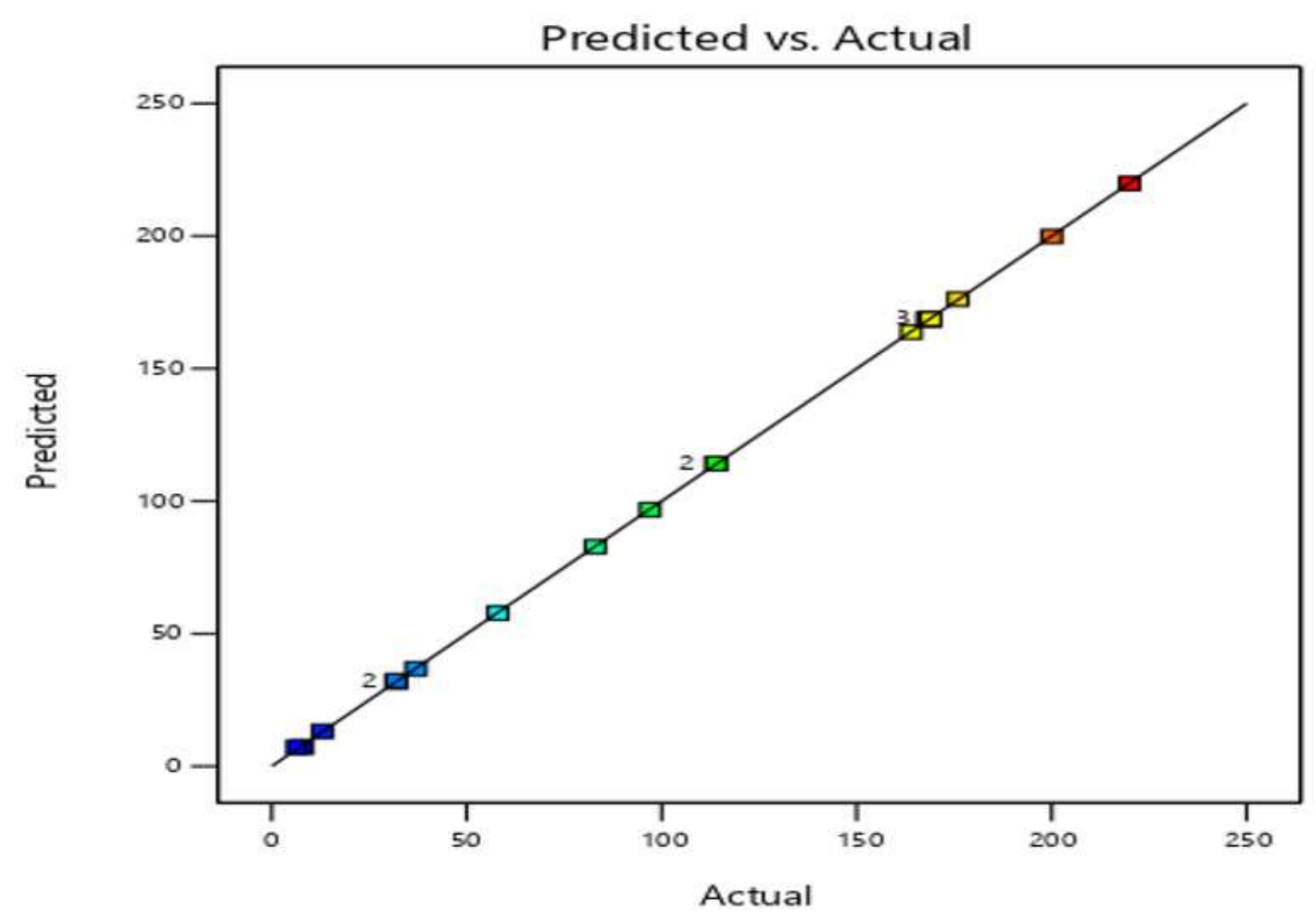

Figure 1

Plot Predicted of the Actual versus Predicted value of the Response 

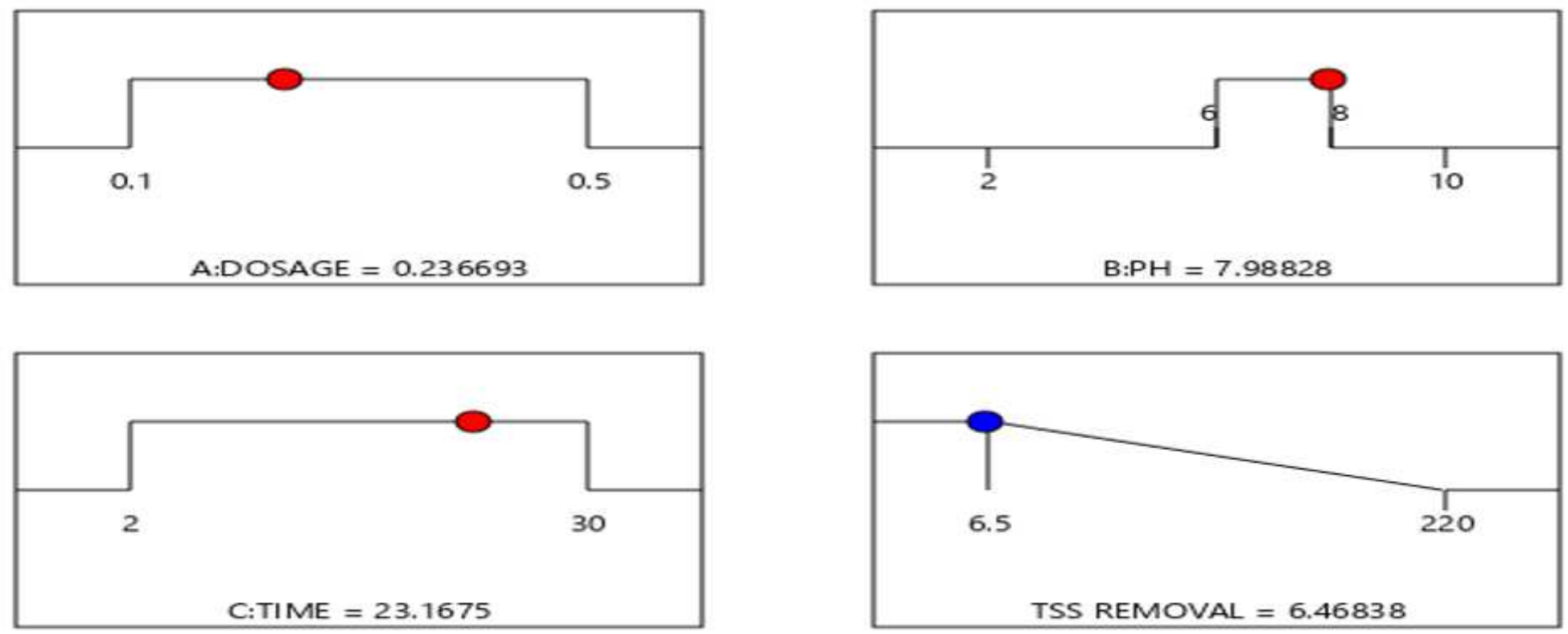

Desirability $=1.000$

Solution 1 out of 93

Figure 2

Desirability ramp plot for the $A B C$ driven coag-flocculation Process
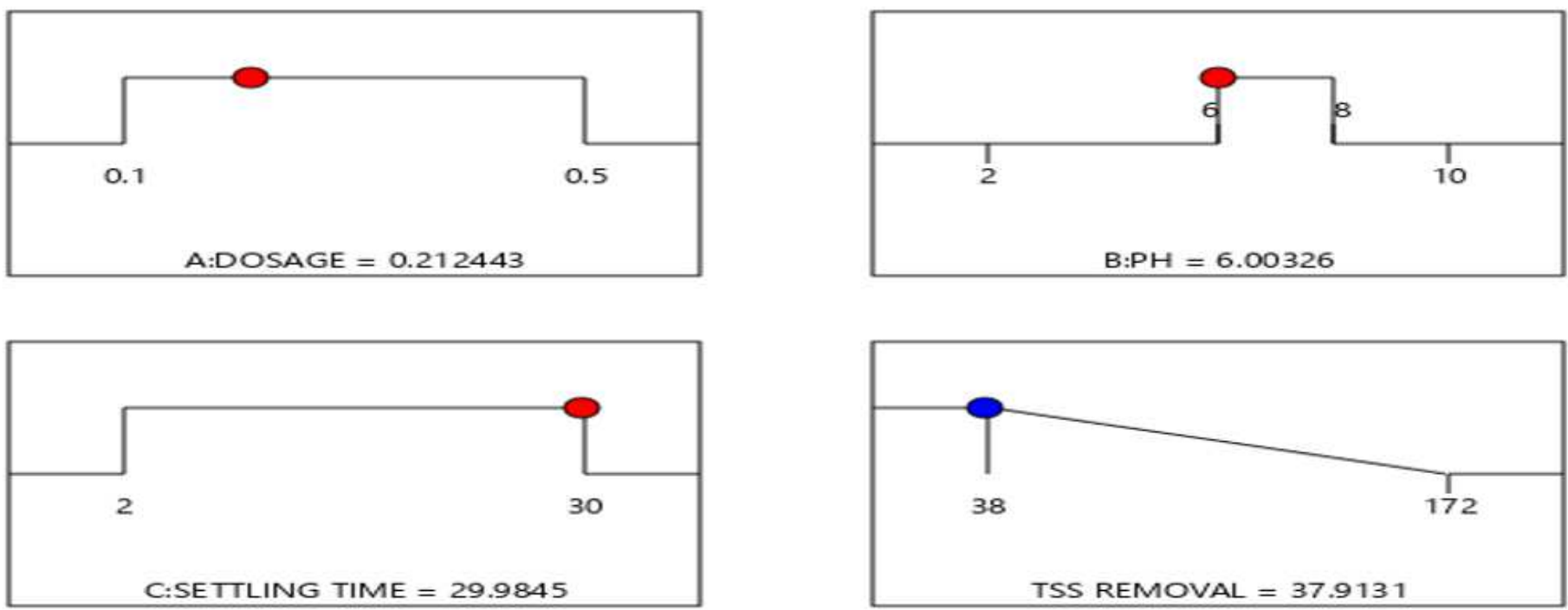

Desirability $=1.000$

Solution 1 out of 67

Figure 3 
Desirability ramp plot for the ESC driven coag-flocculation Process

factor Coding Actual

TSS REMOVAL $(g / L)$

31 172

$\mathrm{X} 1=\mathrm{A}$

$x_{2}=\mathrm{B}$

\section{D Surface}

Actual Factor

$C=299845$

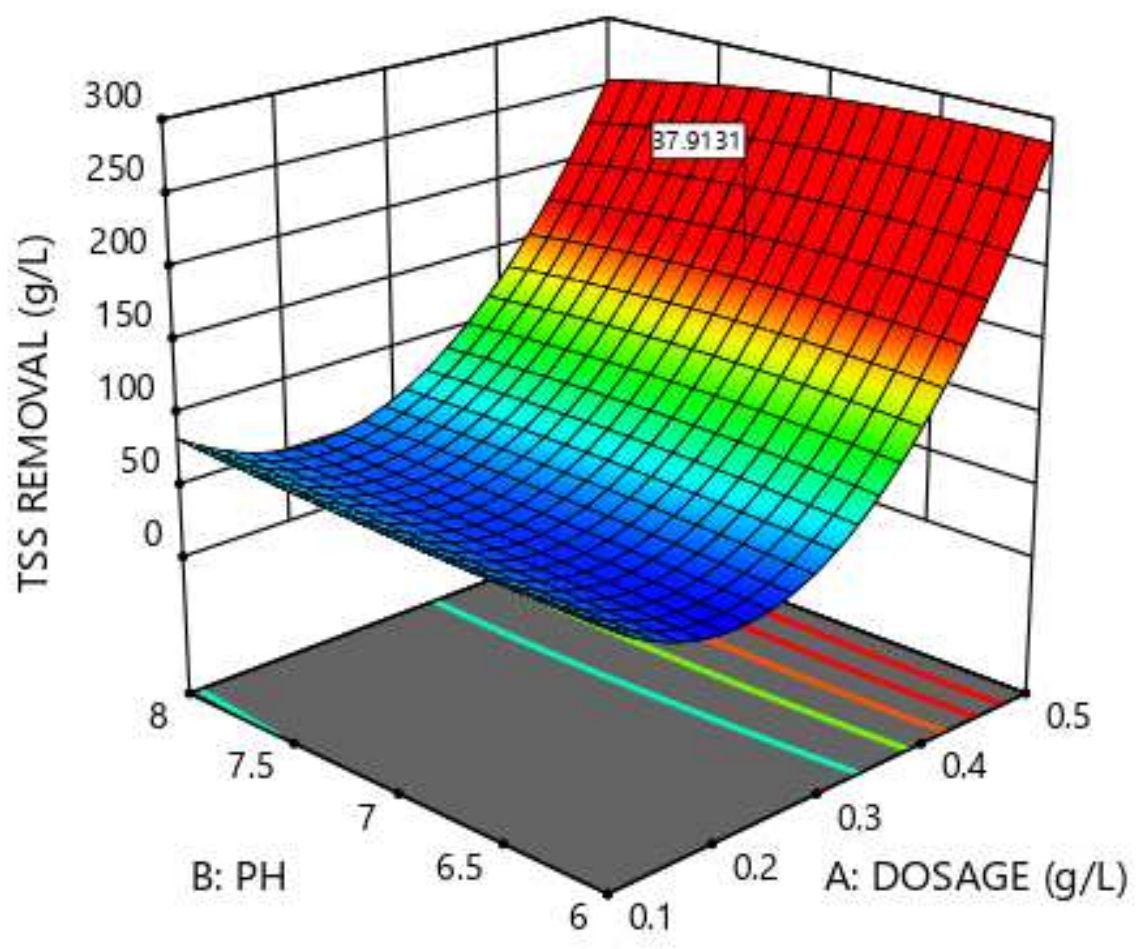

Figure 4

3D Surface Graph showing Residual TSS at optimum points for the ESC coag-flocculation 


\section{D Surface}

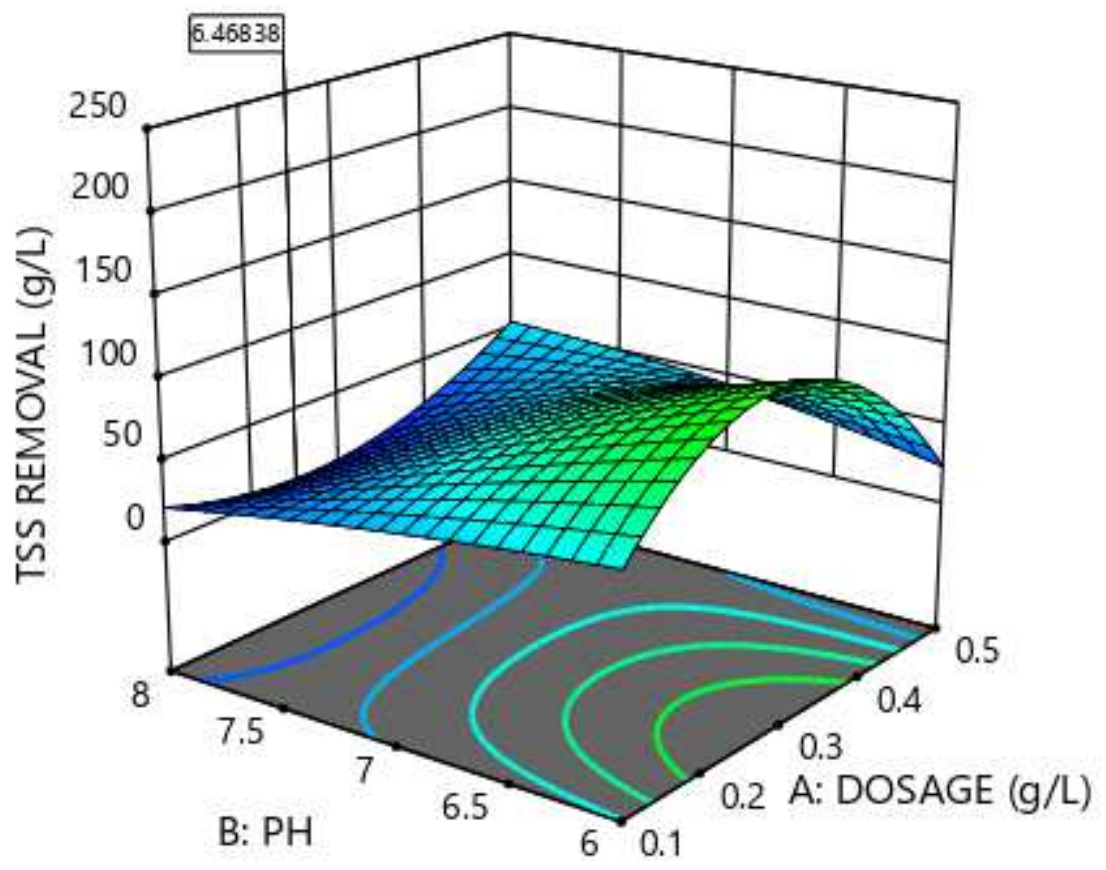

Figure 5

3D Surface Graph showing Residual TSS at Optimum points of ABC Coag-flocculation 


\section{D Surface}

$x_{1}=A$

$x_{2}=c$

Actual Factor

$B=6$

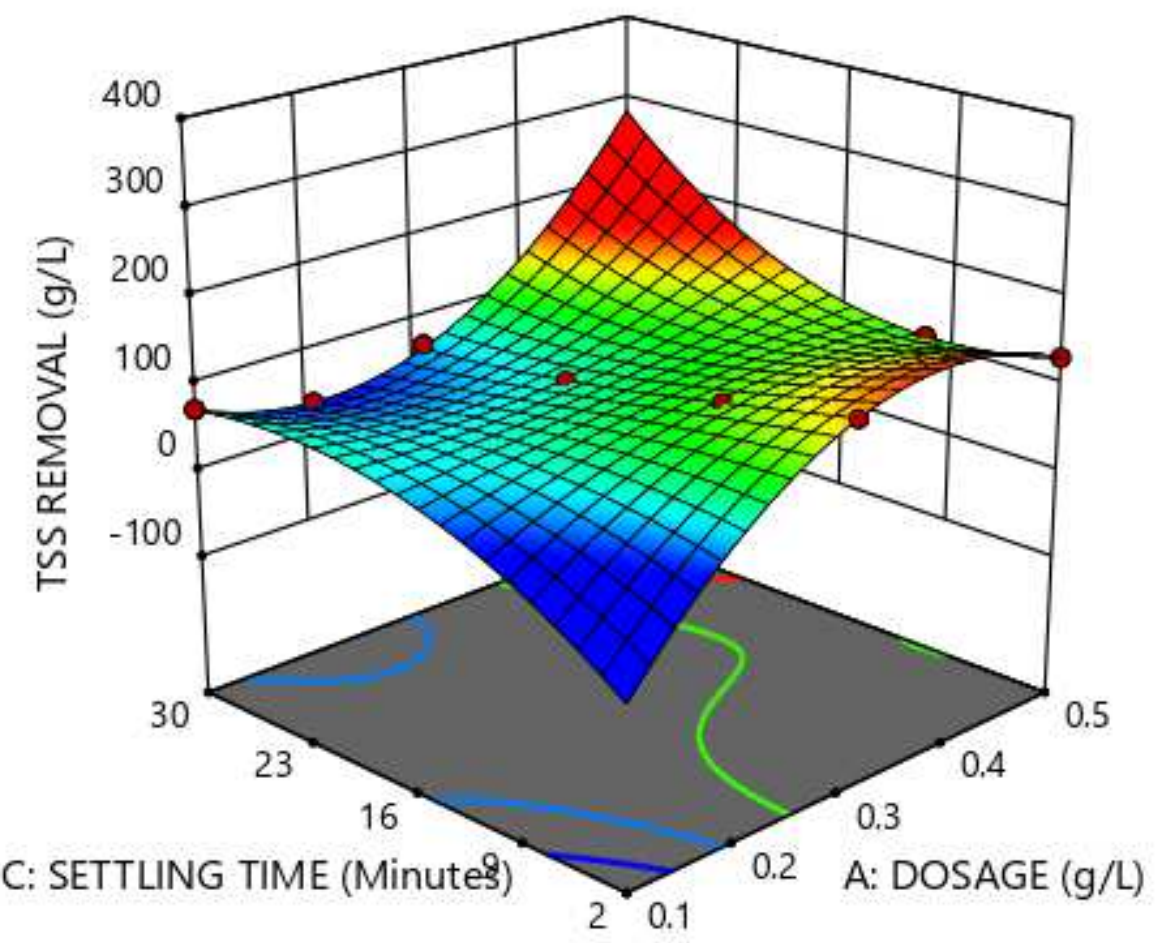

Figure 6

3D Surface on Effect of settling time of ESC 


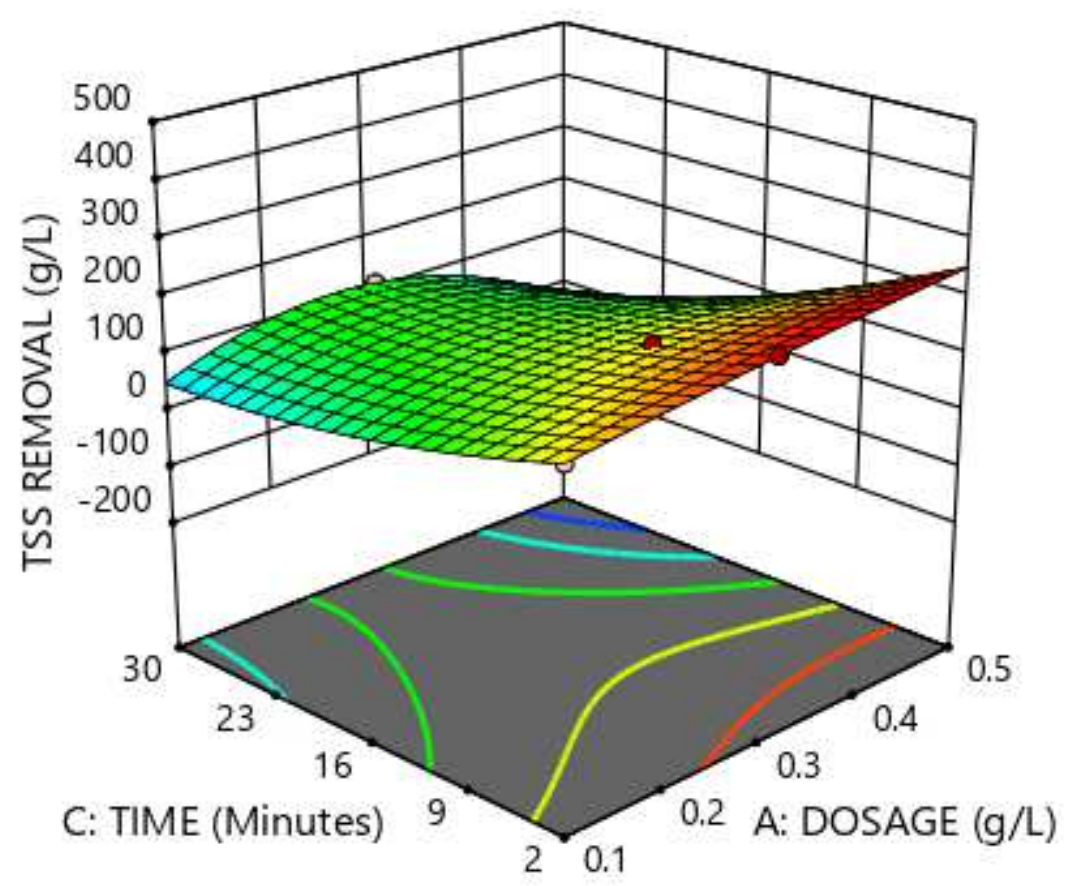

Figure 7

3D Surface on Effect of settling time of $A B C$ 
TSS REMOVAL $(g / h)$

$65 \square 220$

$\mathrm{X} 1=\mathrm{A}$

$\mathrm{X}_{2}=\mathrm{B}$

Actul Factor $C=23.1675$

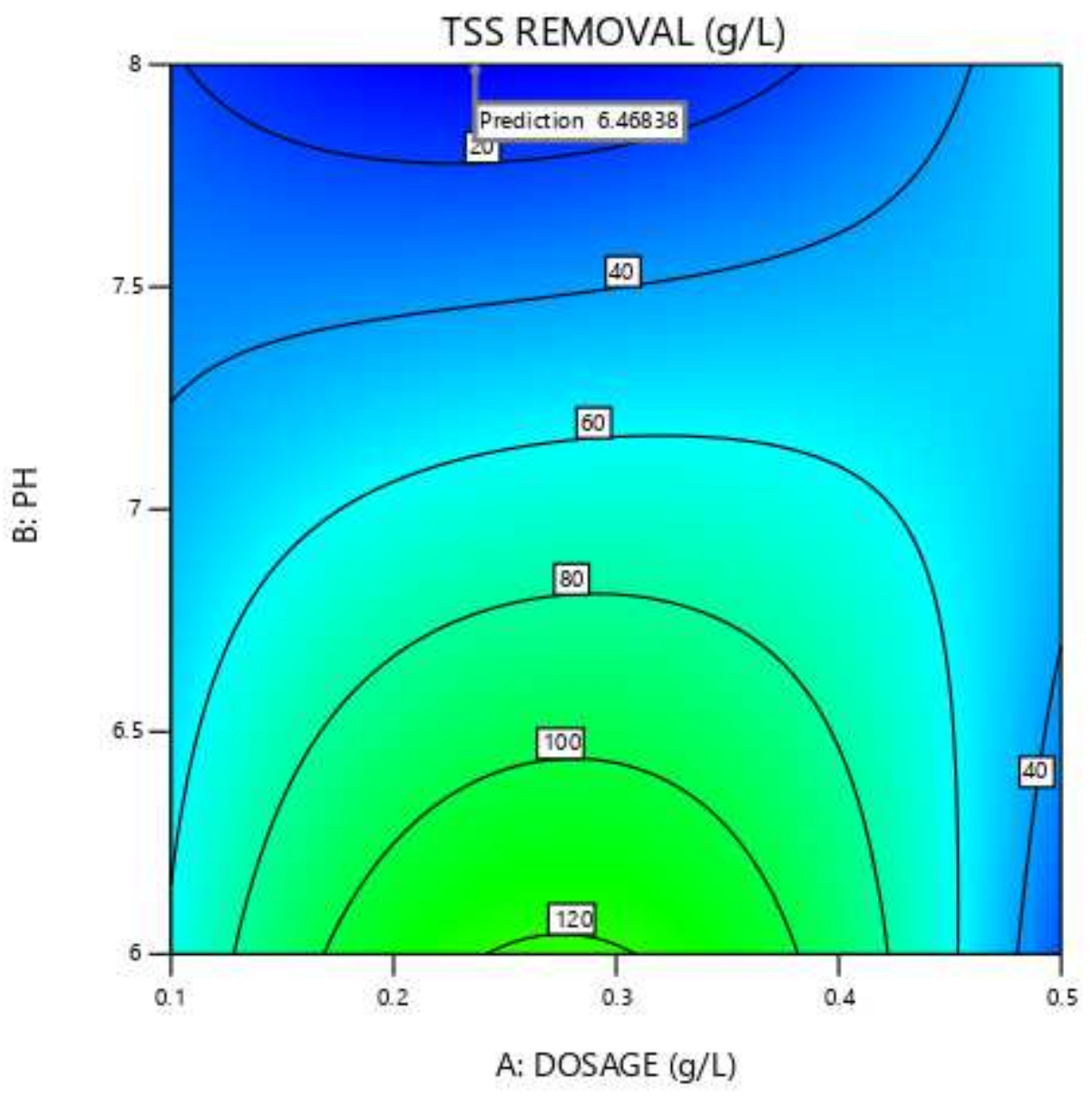

Figure 8

2D Contour on Effect of Dosage of $A B C$ 
TSS REMOVAL ( $g / \mathrm{h}$ )

3) 172

$\mathrm{X} 1=\mathrm{A}$

$X_{2}=B$

Actul Factor

$C=299845$

Figure 9

2D Contour on Effect of Dosage of ESC
TSS REMOVAL $(\mathrm{g} / \mathrm{L})$

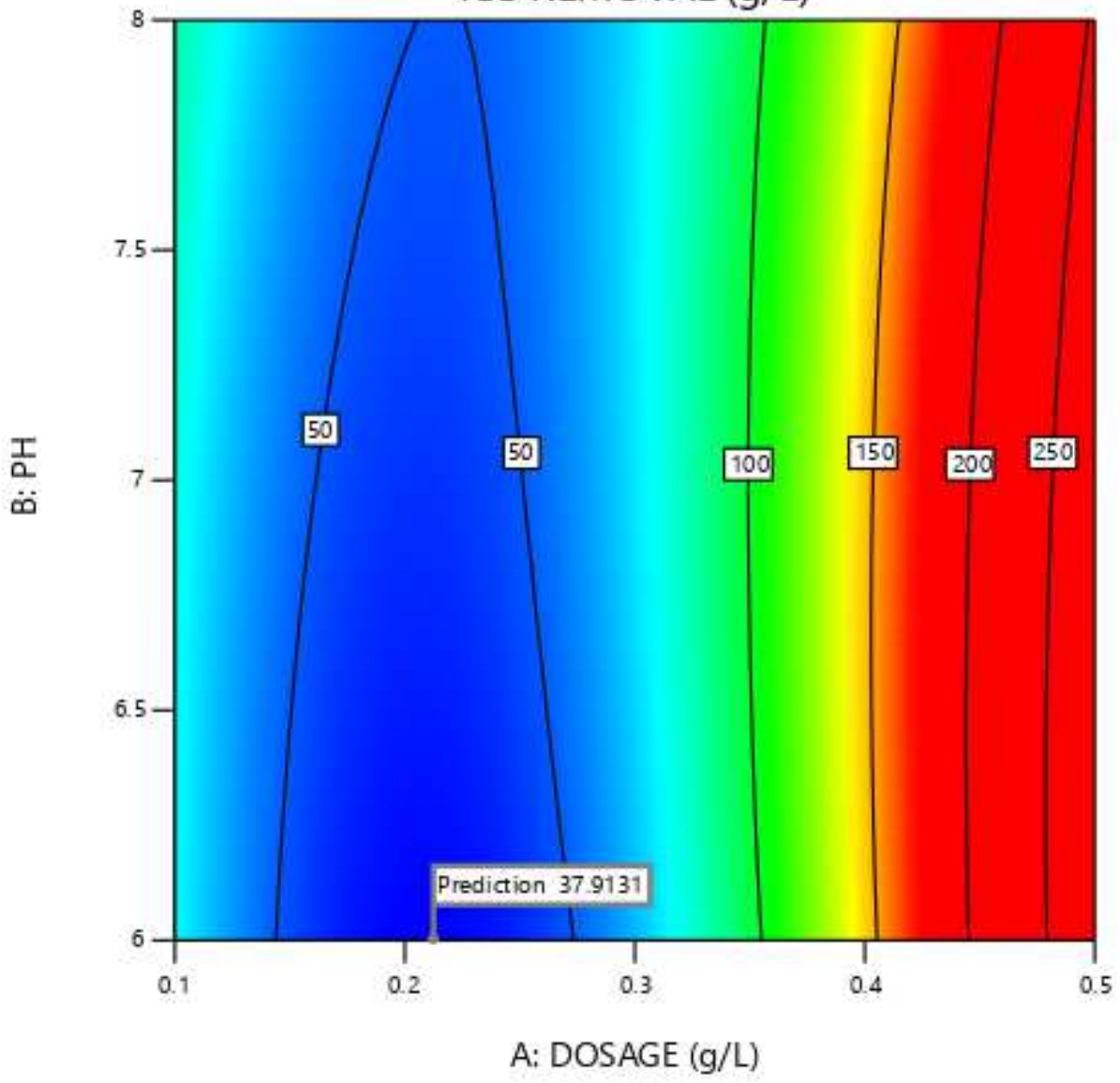

A: DOSAGE $(g / L)$ 
Factor Coding Actual

TSS REMOVAL $(g / \mathrm{h})$

$6.5 \square 220$

$\mathrm{x} 1=\mathrm{A}$

$x_{2}=B$

Actual Factor

$C=16$

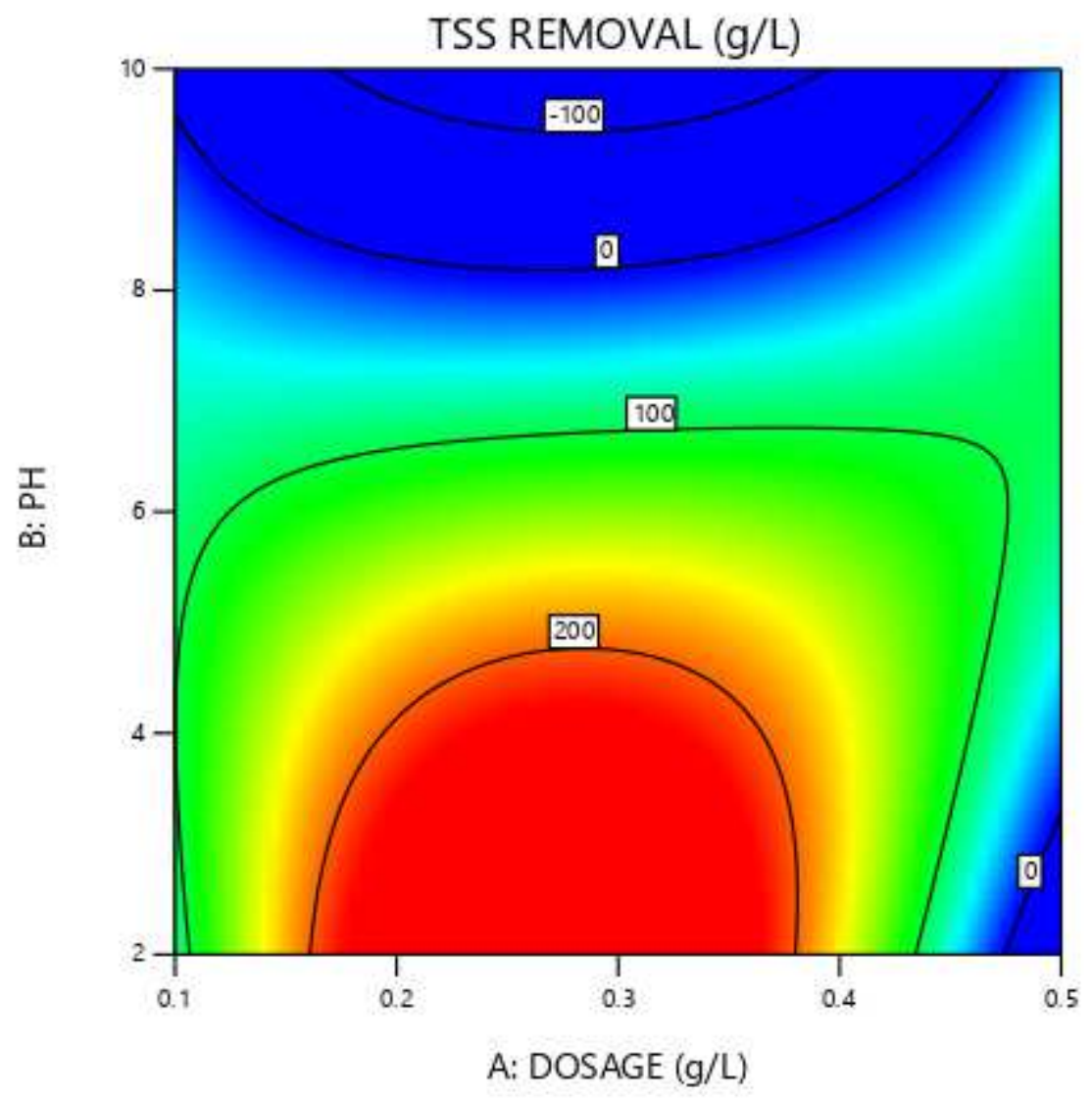

Figure 10

3D Surface on Effect of $\mathrm{pH}$ of $A B C$ 
Factor Coding Actual

TSS REMOVAL $(g /$ )

Design Point

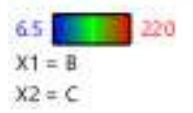

Actual Factor

$A=0.3$

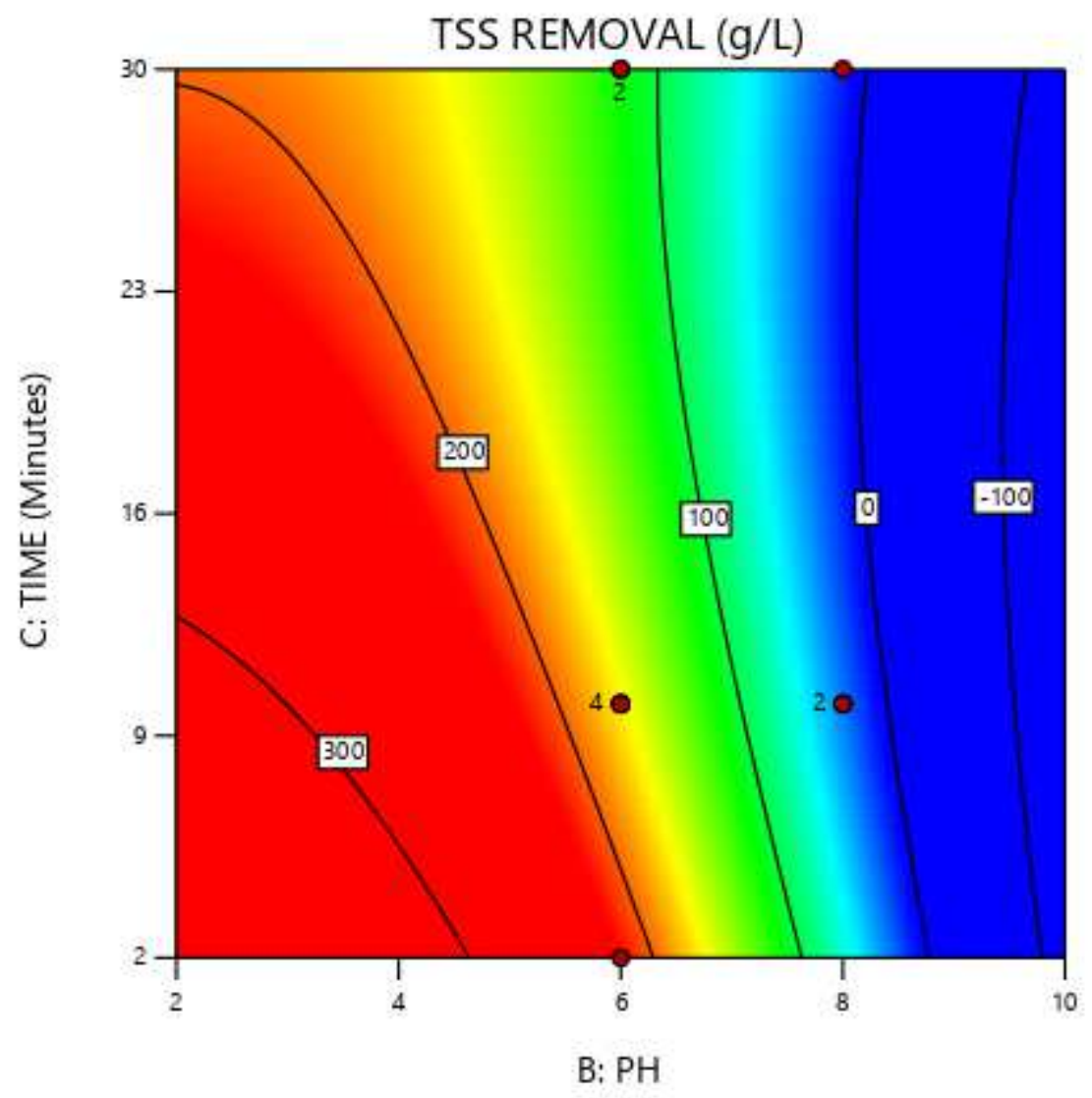

Figure 11

3D Contour on Effect of $\mathrm{pH}$ on ESC 
Coag-Flocculation Rate Constants(L/gMin) ABC and ESC against Dosage ( $g / L)$

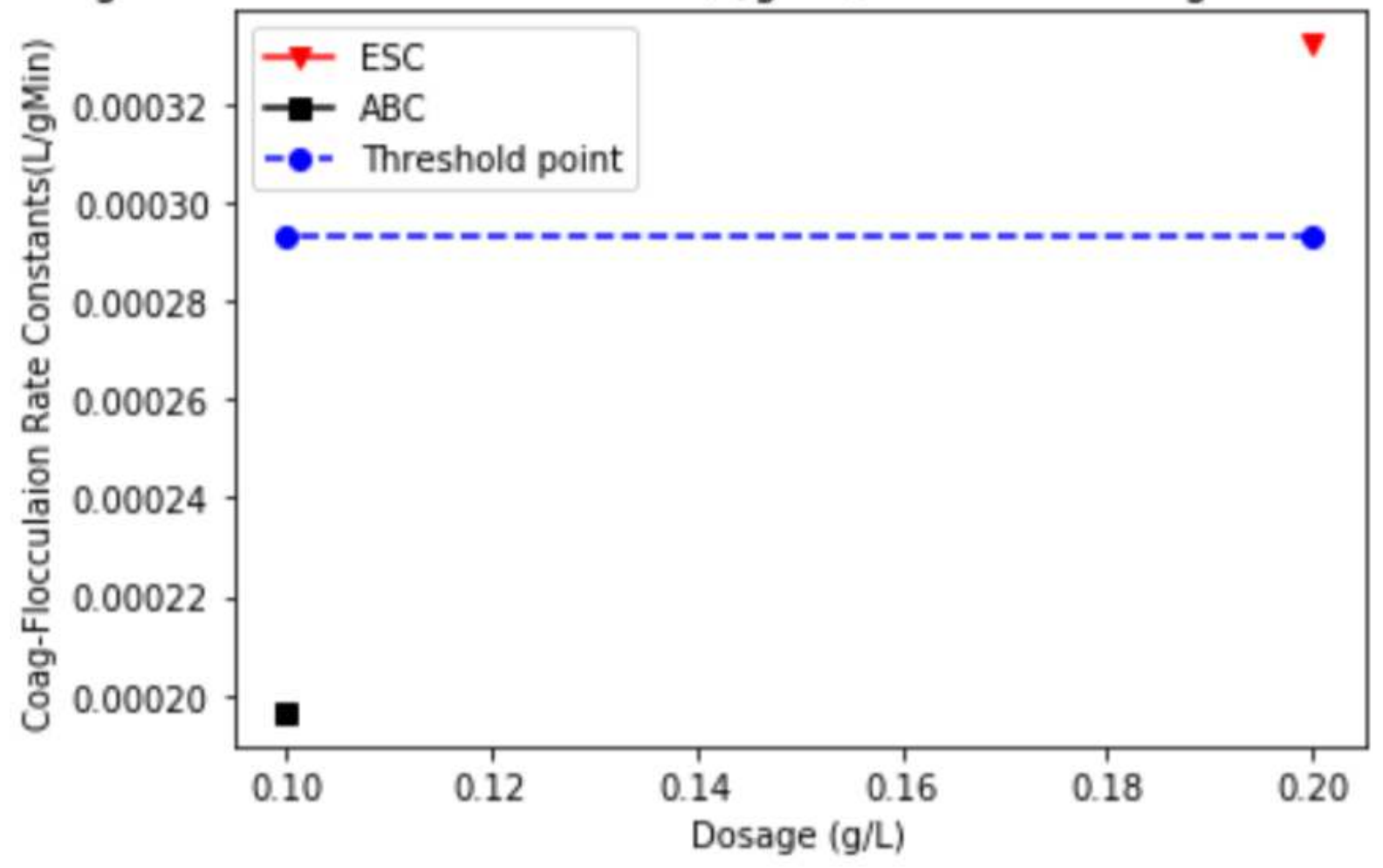

Figure 12

The threshold coag-flocculation rate constant as a point for evaluation factor to compare the efficacy of $E S C$ and $A B C$ at optimum conditions 


\section{Coag-Flocculation Rate Constants(L/gMin) ABC and ESC against Dosage ( $\mathrm{g} / \mathrm{L})$}

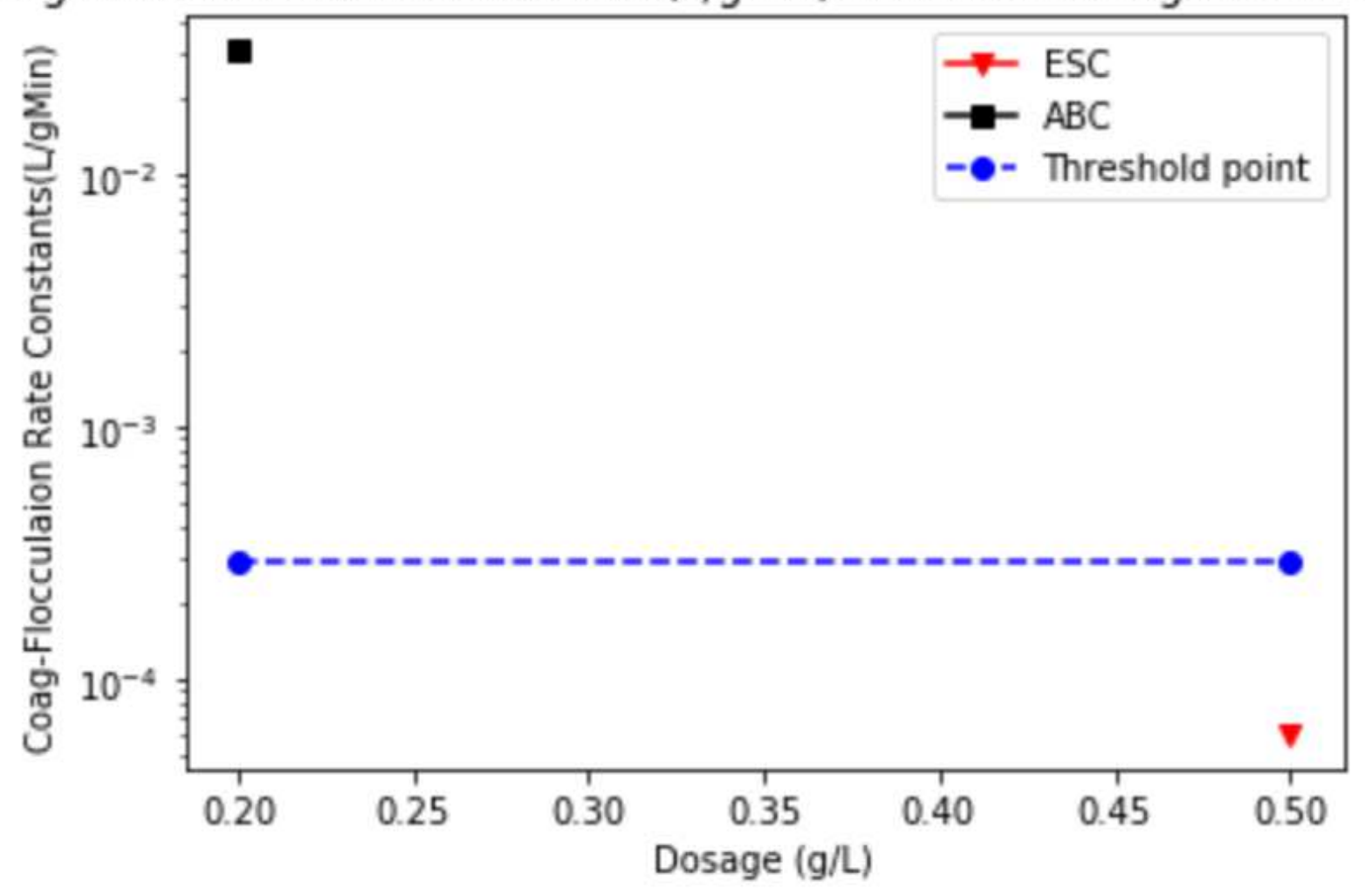

Figure 13

The threshold coag-flocculation rate constant as a point for evaluation factor to compare the efficacy of ESC and $A B C$ at optimum conditions 


\section{$\mathrm{ABC}$ and ESC Cost Chart}

$$
\mathrm{ABC} \square \mathrm{ESC}
$$

150

100

50
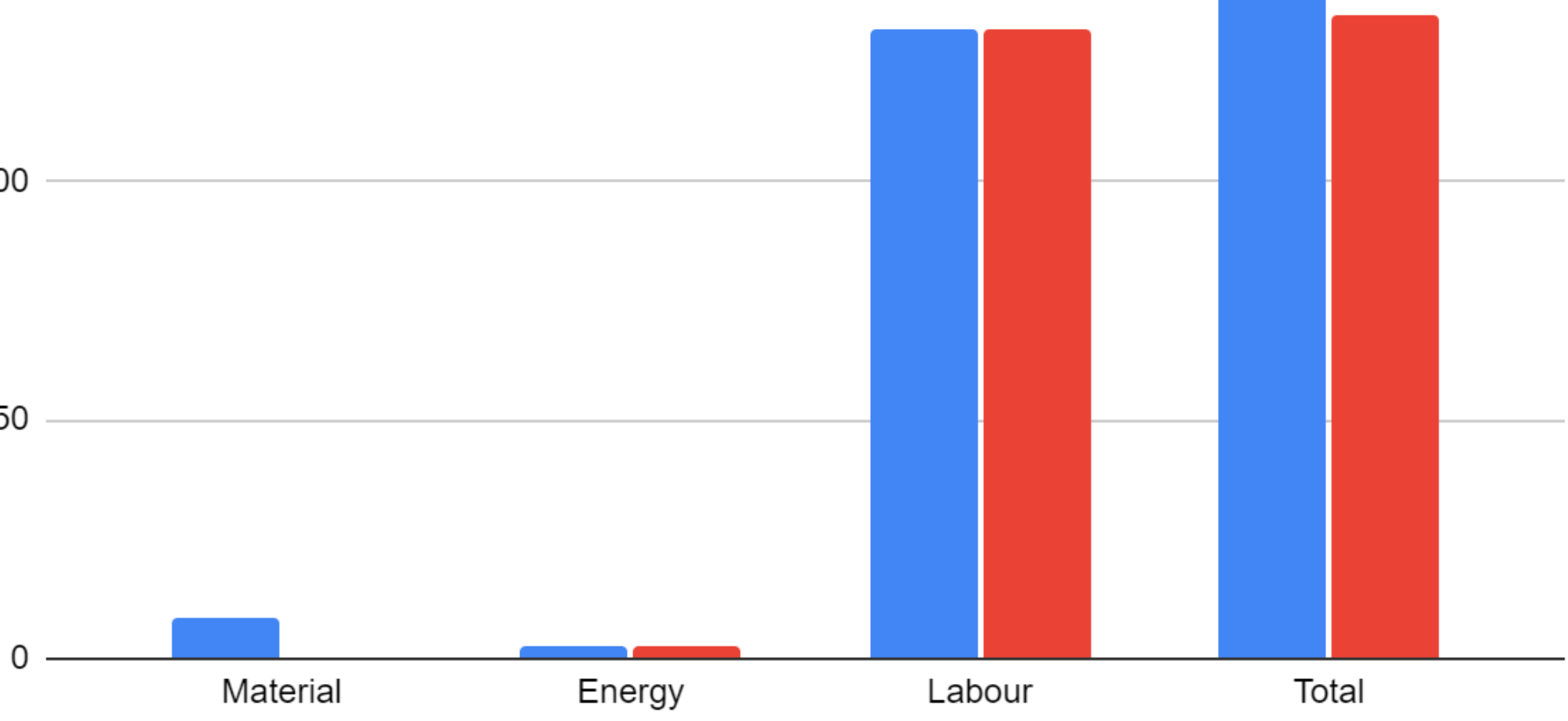

Total

Figure 14

Cost Remediation Chart to compare the ABC and ESC coag-flocculation Treatments 